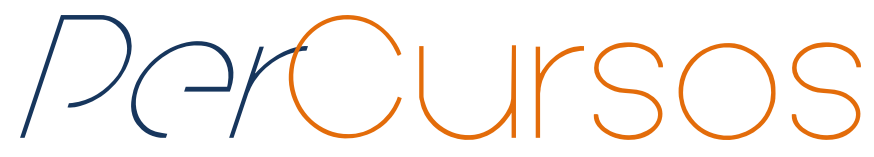

\title{
Do peso do trabalho leve à persistência da alma campesinista: entrevista com Maria Ignez Silveira Paulilo ${ }^{1}$
}

\author{
Entrevistadores \\ Pedro Martins \\ Doutor em Antropologia Social pela Univ. de São Paulo - \\ USP. Professor do Programa de Pós-Graduação em \\ Planejamento Territorial e Desenvolvimento \\ Socioambiental - PGPLAN/UDESC. \\ Brasil \\ weltermartins@yahoo.com.br \\ Tânia Welter \\ Doutora em Antropologia pela Univ. Federal de Santa \\ Catarina - UFSC. Sub-coordenadora do Núcleo de \\ Identidades de Gênero e Subjetividades - NIGS/UFSC. \\ Presidenta do Instituto Egon Schaden - IES. \\ Brasil \\ taniawelter@yahoo.com.br \\ Ivón Natalia Cuervo-Fernández \\ Doutoranda no Programa de Pós-Graduação \\ Interdisciplinar em Ciências Humanas - DICH/UFSC. \\ Brasil \\ icuervof@gmail.com \\ Suzana Morelo Vergara Martins Costa \\ Graduada em Antropologia pela Univ. Federal de Santa \\ Catarina - UFSC. Mestranda em Teatro na Univ. do \\ Estado de SC - UDESC. \\ Brasil \\ suzanamartinscosta@gmail.com
}

\section{DOI: 10.5965/1984724620432019215}

1ttp://dx.doi.org/10.5965/1984724620432019215 ${ }^{1}$ Com a colaboração de Clécio Azevedo da Silva (UFSC), Geraldo Augusto Locks (UNIPLAC) e Marlon
Mendez Sástoque (UCALDAS, CO). 
No dia 14 de maio de 2019, às 10 horas da manhã, a professora Maria Ignez Silveira Paulilo recebeu em sua casa a equipe que se incumbiu de realizar entrevista para a revista PerCursos. Durante três horas, a entrevistada discorreu sobre os mais diferentes aspectos da sua vida, pessoal e acadêmica, resultando em um relato que junta informações relevantes para a história da expansão da pós-graduação no Brasil, sobre os percalços de se fazer ciências humanas em um país periférico e, principalmente, sobre a abordagem científica do mundo rural. Não passaram em branco as recorrentes crises a que os diferentes temas ligados à população rural estão ciclicamente submetidos. A longa conversa, que aqui trazemos na íntegra, com retoques mínimos, resultou em um texto igualmente longo, mas repleto de informações com enfoques muito originais - o que nos brinda com um texto que é, ao mesmo tempo, profundo, prazeroso, emocionante e divertido. Graduada em Ciências Sociais com mestrado em Sociologia e doutorado em Antropologia, Maria Ignez Silveira Paulilo é natural do interior de São Paulo e fez sua carreira profissional na Universidade Federal de Campina Grande e na Universidade Federal de Santa Catarina. Suas publicações inspiraram, e ainda inspiram, diferentes gerações de estudiosos e estudiosas do feminismo e do mundo rural. São quase 50 anos de vida acadêmica que não tiraram desta entrevistada a paixão pelos seus temas e o inconformismo diante de tudo que ainda resta por ser feito - como se pode constatar no texto que segue ${ }^{2}$.

Entrevistadores: Fale sobre a sua trajetória pessoal antes da sua chegada na academia.

Maria Ignez Silveira Paulilo: Eu nasci em setembro de 1950, no interior de São Paulo. Não nasci na cidade onde minha mãe morava. Ela morava em uma colônia japonesa onde os meus pais eram professores, Santa América. Minha mãe costumava ter filhos na casa da mãe dela, como era o costume, em Piracicaba - SP. Mas ela passou mal pelo caminho e acabou ficando em Getulina, na casa de um irmão, e foi lá que eu nasci em 1950. Até quase os quatro anos eu vivi nessa colônia japonesa, Santa América. Eu tenho muitas

\footnotetext{
${ }^{2}$ A equipe agradece ao Núcleo de Identidades de Gênero e Subjetividades - NIGS/UFSC, na pessoa da Professora Doutora Miriam Pillar Grossi, o empréstimo de equipamentos de gravação de áudio e vídeo que tornaram possível o registro da entrevista.
} 
lembranças dos japoneses jogando com uma madeira - baseball, que chama? Eu tinha um medo, com aquela rede no rosto... Eles plantavam café. Meu pai era o diretor da escola e minha mãe dava aulas. Então, eram todos japoneses, os alunos, quase todos. Depois, quando eu fiz quatro anos, nós fomos para uma cidade chamada Ribeirão Bonito, perto de São Carlos, aquela região, também interior de São Paulo, e lá eu fiquei até os 14 anos. Então, eu sou muito de interior, dessa vida de interior mesmo. Como meus avós, dos dois lados, eram de Piracicaba, todas as férias a gente ia para Piracicaba. A minha referência de cidade grande era Piracicaba. Quando eu completei 14 anos meus pais se mudaram para Piracicaba.

Naquele tempo, o ensino médio era o Normal, o Científico e o Clássico. Eu fiz o científico no Sud Menucci, que era um colégio considerado difícil; meus pais estudaram lá, aquela coisa. Quando chegou a hora de prestar vestibular, todo mundo achava que eu ia pra medicina ou pra física, porque eu era melhor em ciências naturais e nessas ciências ditas exatas - que hoje se sabe que não são tão exatas assim. Mas, era uma época de muita efervescência política, muita política... Então, em 1970 eu quis fazer Ciências Sociais, entrei pra Ciências Sociais. Foi interessante porque os meus professores ficaram horrorizados, mas meus pais aceitaram bem, meus pais aceitaram muito bem. Então, eu fui pra Rio Claro que era, naquele tempo, um instituto isolado. Se chamava Faculdade de Filosofia, Ciências e Letras. Hoje pertence à UNESP. Tanto que o CNPq pôs que eu era formada na Júlio de Mesquita e eu risquei. Depois que eu soube que mudou o nome... De 70 a 73 eu fiz Ciências Sociais ali. Quando eu terminei estava muito perdida. Então, Piracicaba tem aquela escola famosa, Escola Superior de Agricultura Luiz de Queiroz (ESALQ/USP) que tinha se unido à USP nessa época, mas ela é bem anterior. Lá tinha um mestrado em Ciências Humanas Aplicadas, com duas opções: Economia Rural e Sociologia Rural. Aí, em 74, eu terminei a faculdade e, enquanto pensava na vida, fui fazer esse mestrado.

Agora, a Luiz de Queiroz é conhecida como mais ligada ao agronegócio, estas coisas, mas na época, na Sociologia, tinha um ramo mais crítico. Era o Albertino Rodrigues, o Oriowaldo Queda, a Maria Ignez Molina, tinha vários professores. O Oriowaldo Queda bem crítico sobre o desenvolvimento rural do Brasil da época e o 
Albertino bem sociólogo, propriamente dito. Estudávamos Durkheim, Weber, tudo aquilo. Havia muitos professores críticos. Quem me ajudou muito na dissertação foi a Maria Ignez Guerra Molina. Ali se estudava agricultura mas tinha muita liberdade, de vários ângulos. Tinha o pessoal nessa linha do que veio a ser a EMBRAPA, tinha gente da Bahia, de Pernambuco, do Maranhão, de todo lugar vinha gente. Era uma diversão, porque eram aqueles agrônomos já extensionistas e nós da Sociologia. Tinha o pessoal mais velho da Sociologia também e tínhamos nós, recém-formados. Brigávamos a aula inteira. Os agrônomos diziam: "Vocês só falam em sistema. Não vai mudar nada? Tudo é sistema, o sistema está errado. Vocês vão fazer o quê?". Depois daquela briga toda, na saída, eles eram os únicos que tinham carro e davam carona pra todos nós.

Quando começou o mestrado no Brasil, por volta de 68, era curtinho, muito técnico, eram dois anos. Aquele mestrado longo veio depois. Como a Ilse Scherer-Warren é antiga como eu, ela fez o mestrado no Rio Grande do Sul e também era curto. Em dois anos você tinha que acabar. Depois, que não tinha mais bolsa, o pessoal ficava seis, sete anos fazendo mestrado e tinha doutorado direto na USP. Quanto foi em 72, 73, acabou esse doutorado direto e foi um desespero de quem ainda não tinha acabado a dissertação, porque aí tinha que concluir o mestrado primeiro.

Eu teria dois anos pra fazer o curso, mas entrei sem bolsa. No segundo ano, eu recebi bolsa e fui fazer trabalho de campo. Todos os professores, na minha época de graduação, estavam fazendo suas dissertações e teses - que a pós-graduação era recente. Então, a gente participava de pesquisa a toda hora. Para a dissertação, eu fiz uma pesquisa de campo em Valparaiso, no oeste de São Paulo, e demorou. Não terminei de jeito nenhum. Eu sei que eu não consegui em dois anos, mas como eu só tinha recebido bolsa no segundo ano, eu tinha direito, então eu continuei. Quando eu estava quase terminando (eu entrei em 74 e terminei em 76), passou a Josefa Salete Cavalcante, de Campina Grande-PB, entrevistando gente para montar um mestrado de Sociologia Rural lá. Ela me entrevistou e resolveram me contratar. Eu entreguei a dissertação e fui embora. Voltei pra defender. Eu lembro que estava pesando 44 quilos - de tanta confusão de ir e voltar. A banca ficou toda emocionada... Meu orientador foi o José Albertino Rodrigues. Ele era parsoniano. Foi o único parsoniano brasileiro que eu conheci. 
Eu não podia nem ver a cara do Parsons [Talcott Parsons], mas ele era apaixonado. Mas também ele dava muita liberdade. Então, eu, como era feminista, já comecei estudando a mulher no meio rural, tentando um arcabouço mais marxista. A banca foi o Oriowaldo Queda e a Heleieth Saffioti, além do Albertino. Dois marxistas mesmo. E eu lá na tentativa e erro. Nosso marxismo era tudo na base da tentativa e erro quando estudávamos o meio rural. O curso era muito quantitativo, mas eu não tinha problema com isso porque eu tinha feito o científico e o professor de estatística no mestrado era o Rudolfo Hoffmann. Ele dizia que eu era a única socióloga que ele conhecia que sabia estatística. Hoje eu não sei mais nada. Numa prova dele eu tirei 10. Ele ficou emocionado e disse: "Isto é raríssimo!" Mais emocionada fiquei eu. Ele me orientou muito bem, ele e outro professor chamado Umberto de Campos que trabalhava mais com métodos não-paramétricos, porque o Hoffmann era economista, se dedicava mais aos paramétricos. Eu fiz a dissertação inteira com o qui-quadrado [teste qui-quadrado de Pearson]. Tinha um monte de tabelas e essas coisas. Então eu defendi e voltei pra Campina Grande.

\section{Entrevistadores: Conte um pouco sobre a sua fase em Campina Grande.}

Maria Ignez Silveira Paulilo: Em Campina Grande era um mestrado muito teórico, nada quantitativo. Era tudo junto, pessoal de Sociologia, Antropologia. Lá eu encontrei o pessoal que tinha estudado no Museu Nacional/ UFRJ, a Giselia Potengy e a Regina Novaes. Tinha a Paola Cappellin e seu marido, o Mario Giuliani, que tinham feito mestrado na Argentina, eram italianos. Era muita gente e o pessoal da economia junto. Lá, eu fiquei encantada com aquele ambiente, com o jeito como elas pensavam, com aquela linha do Museu Nacional. Eu comecei a sentir falta de uma Sociologia própria para o rural, mas isso foi um pouco depois. Eu entrei no doutorado em 1980, iniciei em 1981. Até início de 1979 eu fiquei na Paraíba e, depois, por motivos pessoais, eu vim pra cá, pra UFSC.

Entrevistadores: Como foi a experiência de mudar para a UFSC?

Maria Ignez Silveira Paulilo: Eu estranhei tudo. O mestrado estava começando, era o primeiro ano. Por isso que me contrataram. Na verdade, antes foi contratado o meu 
marido, Marcos Blauth, na área de engenharia. Eu tinha trabalhado no interior da Paraíba e tinha pegado muito sotaque. Eu me lembro que o Idaleto Aued, que era daqui e estava lá fazendo o mestrado (a Bernadete, esposa do Idaleto, estava lá também, ela tinha sido minha aluna no mestrado e somos até hoje amigas), ele falou com o Sílvio Coelho dos Santos. Então, quando eu vim, o Sílvio me apresentou para as pessoas e lembro que uma professora comentou: "Se veio pra trabalhar, está bom". O Sílvio até pediu desculpas. Mas depois é que ela me contou que a história que rolou é que vinha um engenheiro, meu marido, que era gaúcho (sobrenome alemão, tudo o que o pessoal daqui gostava, um gaúcho, engenheiro), que vinha pra Engenharia de Produção, que tinha uma mulher sobrando e que tinham dado emprego nas Ciências Sociais. Então, na cabeça de todo mundo, eu tinha acabado de fazer o mestrado em Campina Grande. Mas, na verdade, eu ajudei a montar o curso de Campina Grande e dava aula e tudo. Com 26 anos eu já era mestre. Eu nem entendi direito quando a Professora Zuleika Lenzi, que me recebeu muitíssimo bem quando cheguei, ao falar sobre mim, disse "o produto saiu melhor que a encomenda". Imaginem o que estava esperando?!

Os professores aqui eram contratados como visitantes e davam aulas no mestrado. Eram todos mestres. Eu era mestre também mas me contrataram para dar aulas no mestrado e na graduação. Os homens, que davam aulas só no mestrado, davam uma disciplina por semestre porque contava o tempo dobrado. Eu já comecei dando duas disciplinas. O professor de Metodologia de Pesquisa, Facchini, havia se afastado e eu já entrei dando Metodologia. Ninguém gostava de dar aulas de Metodologia naquela época. Por sorte, minha formação em Metodologia era forte. No meu tempo não tinha bacharelado e licenciatura em Ciências Sociais. Era muito comprido o curso. Quando olham meu histórico escolar os alunos morrem de rir. Então, eu tive muita Metodologia de Pesquisa, Filosofia da História, Epistemologia e Sociologia do Conhecimento. Eu fui aluna do Rubem Alves, que depois foi pra UNICAMP, e outro que diziam que era monge beneditino (e, no final, era mesmo!), o Benjamin de Souza [Francisco Benjamin de Souza Netto - 1937/2019]. Ele foi o primeiro professor de História da Filosofia Medieval do Departamento de Filosofia da USP e um dos fundadores, em 1992, do Centro de Estudos de Filosofia Patrística e Medieval de São Paulo - CEPAME. Este pensava em grego e 
traduzia enquanto dava aulas de filosofia pra nós. Os rodapés das apostilas eram em grego. Ainda bem que ele tinha paciência. Excelente professor, com uma profundidade tremenda. A gente não entendia nada, mas se esforçava e ele sempre elogiava. Fiz, no mínimo, duas disciplinas com cada um deles. Então, quando eu cheguei aqui, eu fui dar aula no mestrado. Mas, oficialmente, eu não era do colegiado porque eu ainda não tinha orientado nem co-orientado dissertações, embora o Sílvio Coelho, que também me recebeu muito bem e era coordenador do curso, me permitia participar das reuniões com voz e voto. Eu fico meio na dúvida se essa era mesmo a questão ou se era porque eu era mulher e considerada nordestina. Por que, do grupo de mestres, só eu tinha que dar tanta aula, além de ganhar menos do que ganhava na Paraíba? Apesar de eu ser professora da Universidade Federal da Paraíba não fui transferida, tive que me demitir e prestar concurso de novo.

$\mathrm{Na}$ época, eu estava mesmo muito desligada. Não queria ter deixado os amigos, a vida de lá, só vim por causa do meu marido. Tinha tantas dúvidas que não pedi logo demissão, pedi licença sem remuneração da UFPb. Feminista convicta e me vendo na situação de escolher entre família e profissão! Lembro de uma das primeiras reuniões de Departamento em que participei, que um professor disse que tinha gente que fazia concurso e gente que entrava pela janela. Quem entrava pela janela, no caso, era eu! Mas, passada essa primeira fase, não posso me queixar dos novos colegas. Entrei em 1979 e já em 1981 me permitiram sair para fazer doutorado. Passado o mal estar inicial, compreensível já que os outros professores nem foram consultados se me queriam por lá ou não, não sabiam quem eu era, também ficaram sabendo que o contrato era provisório, tudo se ajeitou. Acho que um certo desligamento da minha parte ajudou, eu nem percebia direito o constrangimento que estava causando. Também tinha uma disciplina chamada de Epistemologia da Linguagem que ninguém queria dar e, como eu tive formação nesta área durante a graduação (com rodapés em grego e tudo!), fiquei com esse encargo. Ninguém mais se responsabilizou por ela por um bom tempo. Quem a dava era o prof. Eble [Alroíno Baltazar Eble] que, por problemas de saúde, acabou se afastando. Nada melhora mais o humor de um departamento do que alguém para 
assumir as disciplinas mais indesejáveis: Metodologia de Pesquisa e Epistemologia da Linguagem.

\section{Entrevistadores: Como foi o seu processo de seguir para o doutorado?}

Maria Ignez Silveira Paulilo: Em 1980, eu prestei exame de seleção para o Museu Nacional [Museu Nacional da Quinta da Boa Vista, UFRJ], porque eu tinha me encantado com as pessoas lá formadas com quem trabalhei na Paraíba. Mas, fui com a cara e a coragem porque não sabia nada sobre o Museu (não existia internet...). Fui fazer a entrevista e saí tendo um ataque de riso. Isso porque eu me senti reprovada. As perguntas não eram as que eu estava acostumada. Na banca estavam o Luiz de Castro Faria e o Otávio Guilherme Velho. O Otávio fazia as perguntas e eu não entendia. Então eu pedia para ele repetir. Eu não sei por quê, mas o Castro Farias interferiu a meu favor. Ele disse: "Chega de estudar a miséria do Nordeste!". Porque o Museu, naquela época, tinha aquele monte de livros sobre a zona da cana. Trabalhos maravilhosos, da Lígia Sigaud, do Afrânio Garcia, da Beatriz Heredia... O próprio Otávio tinha estudado a Amazônia, que aí já é Norte. Então, o Castro Faria falou: "Chega de tanta miséria! Vamos estudar o Sul um pouco" - que eu queria estudar a integração [integração entre produtor familiar e agroindústria] aqui no Sul. Para um susto meu, o Otávio me aceitou como orientanda. E que grande orientador ele foi! Eu não tinha muita ideia do que isso, ser aceita pelo Otávio, significava para os concorrentes. Fui saber depois. O Sílvio Coelho me entusiasmou muito pra ir fazer o doutorado porque eles estavam precisando de doutores. Pra se ter uma ideia, na época em que eu comecei o doutorado, o doutor não tinha diferença de salário, ganhava igual, era por amor à arte. Quando eu estava no doutorado, em 1982, saiu o plano de carreira. Mas eu prestei o exame no começo de 80 e estava grávida sem saber, ou logo depois engravidei. Eu acho que eu era pra ir no segundo semestre de 80 mas eu resolvi adiar um semestre. O Otávio não gostou mas aceitou e eu fui em 1981 com a Taís recém-nascida. Ela tinha 54 dias quando eu embarquei pra fazer o doutorado. Ontem mesmo eu estava conversando com ela - que está com um bebê mais ou menos nessa idade. Ela falou: “Mãe, eu não consigo imaginar!”, mas não adiantava eu ter ficado aqui porque o Marcos [Marcos Blauth, o marido] havia entrado no doutorado da COPPE [Instituto Alberto Luiz 
Coimbra de Pós-Graduação e Pesquisa de Engenharia, UFRJ], em engenharia. la terminar a licença-maternidade e nós todos iríamos trabalhar oito horas por dia. Eu já tinha uma ideia do que era ter filho porque aos 17 anos eu tive um irmão pequeno que eu ajudei muito a criar. Mas como nós fomos os dois fazer o doutorado, o Marcos me ajudava muito. Então não foi tão difícil. Mas, mesmo assim, no primeiro semestre eu pedi conceito I nas duas disciplinas. Nunca me arrependi tanto de ter feito uma coisa. A gente pede o conceito I no desespero mas depois se arrepende até a morte. Mas, foi.

\section{Entrevistadores: Como foi o seu retorno a Florianópolis?}

Maria Ignez Silveira Paulilo: Então, eu fiz o doutorado, veio o plano de carreira em 1982, e quando eu voltei o pessoal perguntou: “Você é da Antropologia ou da Sociologia?”. Como falou o Otávio, ele nunca conseguiu me definir. Então ele me chamava de Cientista Social. Como eu já era do grupo da Sociologia, eu falei: “Eu fico na Sociologia mesmo, mas eu quero fazer Sociologia Rural, não interessa de que jeito".

É engraçado que durante os quatro anos que eu fiquei no Rio, o departamento mudou completamente. Quando eu cheguei, estranhei muito. Porque em Campina Grande a gente trabalhava como uns loucos. O Lynaldo Cavalcanti de Albuquerque era o Reitor. Ele aumentou muito a Universidade e dava muita liberdade. Ele contratou muita gente que era considerada marxista na época e não estava sendo contratada em outros lugares. Tinha o José Grabois - que só o sobrenome já... A gente acreditava muito em fazer um mestrado mais crítico sobre o desenvolvimento rural no Brasil, aquela modernização da agricultura, a gente lá em pleno Nordeste. Então, a gente tinha muita vontade de fazer as coisas, a gente se reunia toda hora, era uma coisa! Coletivo, coletivo mesmo. Quando eu cheguei aqui [na UFSC] eu estranhei tudo, tudo. O jeito de ser, por exemplo. Começa que eu não sou sulista, sou do interior de São Paulo. Aqui não tinha nada coletivo. No Nordeste, você chegava e já era convidado pra casa de todo mundo. Aqui eu não sabia se as minhas amigas eram casadas ou não... Só Sílvio Coelho nos convidou pra um jantar, foi ótimo, na casa de praia dele. Tanto que eu criei o costume, por muito tempo, que todo professor novo que chegava eu convidava pra almoçar, 
porque eu fiquei muito chocada. Depois mudou tudo, mas por muitos anos todos os professores novos que eram contratados pelo departamento eu convidava pra um almoço, aqui ou na casa de praia. Pra eles se sentirem bem recebidos, porque eu estranhei demais.

Na verdade eu tinha ficado pouco tempo aqui. Cheguei em 79, fiquei 80 e em 81 já fui para o doutorado. Então, quando eu cheguei de volta em 85 foi a tragédia. Eu fiquei viúva, perdi meu marido num acidente, foi muito ruim. Eu não tinha acabado o meu doutorado ainda. Por isso que eu tenho muita paciência com quem atrasa. Nem o CNPq nem a CAPES deixam a gente ter paciência, mas, olha, é duro. Aí, não houve meio. No primeiro ano eu não consegui trabalhar. Eu vivia a base de remédio e então eu resolvi trabalhar normalmente e deixar a tese de lado. O Sílvio, sempre atencioso, me disse para dar as minhas aulas e não aparecer em outras atividades, me concentrando na tese, mas eu não conseguia me concentrar. Então, no ano seguinte, já um pouco mais lúcida, eu resolvi terminar. Mas era brabo porque a gente dava muita aula. Muita, que eu falo, é na graduação e na pós. Mas tinha muita coisa pra fazer, o mestrado estava começando e tudo. Quando chegou no segundo semestre de 86, me destinaram uns cursos novos e os cursos não tinham a mesma duração na graduação. Um dos mais compridos era o de Metodologia da Pesquisa, que tinha 5 créditos - dava a aula em dois dias, três horas em um dia e duas em outro, mais a pós. Então, teve uma reunião um dia em que iam discutir o meu caso e eu não fui - porque achei que não pegava bem eu ir lá e defender minha própria causa. Depois, me contaram como foi a reunião. Os amigos, ou melhor, as amigas, queriam que eu ficasse com apenas uma disciplina no último semestre de 1986, para terminar a tese cujo prazo era fevereiro de 1987. Mas, o mestrado estava se estabelecendo e o pessoal mais qualificado não estava querendo muito se dedicar à graduação, queriam ficar só no mestrado, mas eu era professora da graduação desde que cheguei. O que aconteceu então (depois me contaram): as mulheres se levantaram e se uniram a meu favor, mas os homens, mais carreiristas, todos contra. No final, eu fiquei com só um curso de pós, graças às mulheres, principalmente a Ester Jean Langdon, e consegui terminar a tese, mas eu achava que não ia terminar nunca. Quando eu terminei, era Páscoa de 1987. Eu peguei a tese, coloquei um laço de fita em volta, coloquei na mesa 
da secretaria e enchi de ovinhos de chocolate em volta. Porque eu achei que nunca ia terminar. O Museu entrou em greve e eu só defendi em julho, mas eu tinha que entregar em 28 de fevereiro - era o meu prazo final.

As minhas deadlines sempre foram terríveis. Eu tive que entregar meu projeto em 28 de fevereiro também. A gente passava os verões aqui, a Taís, minha filha, tinha completado dois anos em 15 de janeiro e eu tinha que postar no correio até essa data, 28 de fevereiro! O orientador era muito compreensivo, mas tinha que cumprir aquele prazo. Aí eu levei o projeto para pôr no correio. Eu tinha uma Brasília. Chovia a cântaros, como chove aqui. Eu estava tão atordoada que bati a porta da Brasília não só com a chave dentro, como o motor funcionando. E o projeto lá dentro. E eu tinha que pôr no correio. Por sorte, o porta-malas não estava fechado. Naquela época eu estava com 32 anos, era muito atlética, então dei um jeito e entrei na Brasília pelo porta-malas. Minha preocupação era só botar o projeto no correio. Então, quando foi o 28 de fevereiro para entregar a tese, o meu orientador, que foi muito solidário quando eu enviuvei, me sugeriu a possibilidade de trancar o doutorado por um ano, já que meu departamento não me dava trégua. O problema é que, como saiu o plano de carreira valorizando a titulação, muitos colegas decidiram sair para o doutorado, faltava professor. Tinha o curso de graduação da manhã e o curso da noite. Agora, imagine: eu viúva com uma criança. Quem ia ficar com ela? Peguei curso sábado. Eu tive que contratar uma empregada, que eu dava a segunda livre, para ela poder vir no sábado. Eu dei aula com a Taís no colo. Eu já era feminista e fiquei ainda mais. Com muita gente saindo para o doutorado, o que sobrava de serviço não era fácil. E tinha muito horista. Não sei se algum de vocês chegou a ser horista [sim, todos fomos], mas tinha muito horista pra dar conta das aulas todas. Aí, graças a Deus, eu defendi essa tese.

Eu não acho que minha tese ficou assim muito amarrada. Porque os trabalhos do Museu tinham a característica de serem muito amarrados teoricamente, muito fluidos, muito literários. Minha tese não ficou assim, não. Ela ficou muito truncada. Tanto que o Otávio, com a delicadeza que sempre teve, aquela elegância só dele, disse que quando eu havia entrado no Museu tinha cabido a ele me domesticar, mas que, felizmente, ele não tinha conseguido. Aí, pronto, eu era doutora. Eu não queria nem ver a cara da minha tese, 
de tão cansada. Mas, a Pós-graduação precisava muito ter uma boa nota na CAPES e então o Viola [Eduardo José Viola] me amolou tanto para publicar meu trabalho que, em 1990, ele saiu publicado. Mas era muito grande, eu cortei um pedaço inteiro, toda a parte sobre a avicultura, deixando só a da suinocultura e a da fumicultura. Aí saiu o meu primeiro livro: "Produtores e Agroindústria, consensos e dissensos", que é a minha tese de doutorado. Se vocês lerem (agora não faz mais sentido), era a discussão da época; “O que é o rural?", essas coisas, era a discussão da época. Tanto que, por exemplo, quando eu fazia mestrado, só se falava em agricultura de subsistência. Aí, saiu um plano nacional que passou a chamar a pequena agricultura de "agricultura de baixa renda", mudou o nome. Então eu fui fazer um estágio no Maranhão com duas amigas, a Marisa e a Marta. Naquele tempo, tudo era longe. Eu não conhecia nada do Norte e Nordeste nessa época, fui conhecer logo o Maranhão. Aí você vê que tem que pensar de outro jeito, não sei como, e a gente estava procurando os caminhos pra pensar, uma loucura! A Nazareth [Maria de Nazareth Baudel Wanderley] falou uma coisa certa. Quando surgiu o conceito de agricultura familiar, nos anos 1990, foi a única vez que se respeitou, que se deu um nome não pejorativo a essa realidade do campo. Agricultura familiar é um conceito que deixava de lado um olhar preconceituoso. Porque antes era "agricultura de subsistência", “agricultura de baixa renda”, eram todos nomes que significavam pobreza, carência.

Quando eu cheguei aqui, eu queria fazer Sociologia Rural, mas na época já estavam trabalhando com isso a Zuleika Mussi Lenzi e o Júlio Wiggers. Eles davam a disciplina de Rural na graduação. Aliás, a Zuleika fazia um trabalho de pesquisa muito interessante no oeste de Santa Catarina, do qual participei. A disciplina Sociologia Rural já estava coberta, pra onde eu fui? Para a Metodologia de Pesquisa que ninguém queria dar. Agora, o professor de Metodologia nessa época sofria o maior preconceito porque se achava que só usávamos aqueles livrinhos importados, que vinham dos Estados Unidos, que ensinavam a fazer levantamentos quantitativos. Eu tive uma graduação cheia de filosofia, mas o pessoal achava que a gente não sabia nada de nada. Então, falavam as coisas mais tolas pra gente e eu nem entendia a provocação porque eu não sabia como era pensar daquele jeito tão limitado. O pessoal me fazia umas perguntas assim pra cutucar. Por exemplo: “Você já leu Feyerabend, 'O Mito do Método”"? Uma vez eu 
respondi pra eles: “Olha, ele escreveu 'O Mito do Método' e não 'Os Mitos dos Métodos"”. Aí uma colega gostou muito. Eu não sou a favor do método, mas dos métodos eu sou.

Eu tive bons orientadores, eu acho. Albertino Rodrigues [José Albertino Rodrigues] e Otávio Velho. O Albertino Rodrigues tinha uma teoria só dele: que quanto mais verde a gente ia pra campo, melhor. Se você quer saber o que é sofrer, é isto: ir verde pra campo. O que eu passei na minha dissertação de mestrado! Eu fiz todo o campo pra depois chegar à conclusão que devia ter feito um campo diferente. Pra terminar a minha dissertação, eu entrava nas poucas cabines telefônicas de Valparaíso e ligava para o Albertino, em estado de surto. Então, o Albertino ouvia tudo e dizia: "Você percebeu que você mesma já resolveu o problema?", aí eu acalmava e, assim, terminei a pesquisa. Mas eu nunca mandei aluno verde pra campo. O Albertino trabalhava com pesquisa, era um bom pesquisador. Mas esta teoria de que você deve ir verde para o campo, eu não sei onde ele achou. Depois eu fui orientada por Otávio Velho que foi um excelente orientador. Ele era de campo, antropólogo mesmo. Aí que eu vi que você não pode ir para o campo sem estar preparado, tem dó!

Mas, como você era professor de Metodologia, todo mundo achava que você era a favor da neutralidade científica... Mas o pessoal fazia pergunta desaforada mesmo, tipo: “Você não acha que os entrevistados podem estar mentindo?”. Ora, por isso mesmo é que é preciso ser treinado para fazer entrevistas. Os alunos também tinham um pouco de resistência. Uma vez eu fui dar um curso de epistemologia, bem quando eu cheguei aqui, 1979/80, e eu dava Durkheim, Weber e Marx, que são os grandes sociólogos, e eu dava a parte epistemológica de seus trabalhos. Os alunos resolveram que não queriam saber aquilo. Um pessoal, na época era Libelu [Liberdade e Luta, movimento trotskista], uma vertente política, pediu pra assistir minhas aulas. Mas eles iam lá só pra falar contra. Achavam que só valia a pena ler Marx e seus seguidores, o resto era perda de tempo. Eu não estava conseguindo dar aula. Aí, eu acho que foi a Regina Novaes que contou uma história que me serviu de exemplo. Eu não tive dúvida. Eu peguei um trecho do "AntiDühring", do Engels, mas escolhi um pedaço bem bonitinho em termos do naturalismo e evolucionismo da época. Dei na prova e pedi para os alunos interpretarem. "Este é um 
positivista sem vergonha...”. É claro que o positivismo no tempo de Marx e Engels era uma revolução. Depois, com o Círculo de Viena, os positivistas mesmo tiveram que fugir do nazismo porque o que eles propunham, estudar a realidade como ela era, já era revolucionário. O próprio evolucionismo também era considerado revolucionário. Eles esculhambaram com o texto até que eu falei: “Gente, este texto é o Anti-Dühring...”, aí eles se acalmaram e eu consegui dar aula.

Quando eu cheguei aqui tinha a disciplina de Epistemologia da Linguagem - quem dava era o Eble. Agora, eu dei Epistemologia da Linguagem sem me ater só à questão da linguagem, que conhecia pouco. Tinha estudado rapidamente Wittgenstein com o Rubem Alves na graduação. Ninguém queria dar. O Eble adoeceu e não dava mais, então caiu pra mim. Aí eu dei as Epistemologias que eu tinha tido na graduação, pois meus professores eram filósofos mesmo e respeitados. Fiquei com essa Epistemologia e com a Metodologia de Pesquisa. Depois, quando foi em 89, aconteceu a coisa mais interessante do mundo. Eu fui na ANPOCS e foi quando começou a quebra dos paradigmas todos. Todo mundo só discutia metodologia! Mas essa era a minha área e eu queria escutar outras coisas, eu estava enjoada daquilo. Aí uma pessoa chegou pra mim e perguntou: "Escuta, Ignez, o que é esse tal de individualismo metodológico?", aí, deu uma virada. Em alguns mestrados nem tinha aula de metodologia porque achavam bobagem. A teoria supria tudo. Aqui, sim, tinha metodologia. De repente, foi um tal de valorizar a metodologia e ninguém queria dar, como sempre. Daí, graças a Deus chegou o Paulo Freire Vieira, que era formado em epistemologia, entre outras coisas, e a gente alternava a Metodologia pra eu dar [Sociologia] Rural na graduação. Na pós tinha gente interessada, mas pouco. Rural nunca foi o forte aqui porque o mestrado daqui abriu caminho, no Brasil, com temas que, na época, eram mais originais. Porque já existiam os programas mais estabelecidos, no Rio, São Paulo. Então, aqui, Ecologia Política e Movimentos Sociais foram os temas de ponta. Os alunos vinham pra isso e vinham muitos que não eram da área de Sociologia. Aconteceu até, uma época, que tinha muitos professores horistas (não que os horistas não fossem bons, mas eles tinham que dar quatro disciplinas enquanto os efetivos davam duas) e, em virtude disso, os nossos alunos de graduação não estavam conseguindo mais entrar no nosso mestrado. Então, tinha que haver uma mudança e reforçar a graduação. 
Nessa época, vinha muita gente de outras áreas por causa da ecologia e dos movimentos sociais - porque isso abalou todas as áreas de humanas.

Então, tinha demanda pelo rural na graduação, mas pouca. Depois foi que virou optativa. Eu ofereci uma vez a disciplina e não teve os 12 alunos que precisava [mínimo para fechar uma turma]. Eu fui dar aula na Educação Física, que foi o que sobrou. Esporte, de esporte eu não entendo nada. Eu tenho vergonha do que aconteceu. Eu fiz esforço pra dar certo, isso já com o curso começando. Mesmo disciplinas que eu dou sempre, eu preparo tudo antes. Não consigo começar um curso sem estar tudo pronto, o curso completo e o programa entregue aos alunos. Os alunos de Educação Física tiveram que ter paciência. Eu tinha que estudar o corpo, o papel dos movimentos, tudo já dando aula. Eles pediram um dia pra não assistir aula pra assistir um jogo do Real Madri. Gente, eu não sabia o que era o Real Madri! Eu pensei que fosse qualquer coisa. "Ah, não! Vocês têm que estudar". Mas os alunos eram muito educados. Então, a cada hora saía um para contar como é que estava o jogo. E eu lá, dando Sociologia da Educação pra eles. Quando eu saí, a Universidade estava parada, um monte de funcionários em volta de uma TV para ver o Real Madri. Aí que vi o que eu tinha feito. Eu fiz um esforço enorme, mas me cansei demais. Porque eu não tinha ideia do assunto, comprei livro de educação física, sobre o corpo, fiz um esforço enorme, os alunos ajudavam. Mas aconteceu uma coisa estranhíssima nessa aula. Eu me apoiei em uma mesa e os parafusos estavam soltos, eu não percebi. Quando apoiei, a mesa se estatelou e eu caí por cima. Eu levantei e nem percebi, continuei dando aula, eu era caxias à beça. Os alunos começaram a falar: “Professora, senta, respira". Eu tinha catarata precoce e usava uns óculos que a minha cunhada tinha comprado no camelô, que eram os únicos com que eu conseguia fazer certas coisas, e o maldito quebrou. Então eu não ia conseguir nem outro. Passou. Depois, eu apoiei uma segunda vez e a mesa caiu. Eu já tinha avisado a secretaria. Na segunda vez que a mesa caiu eu não caí, mas eu tive um ódio tão grande... Eu falei: "Gente, não podem expor os professores a este tipo de acidente". Eu catava os pedaços da mesa e jogava na grama lá fora. Os alunos tudo ajudando. Aí eu catei um pedaço da mesa, fui na secretaria e joguei assim no balcão. Os funcionários que estavam trabalhando ficaram assustados. Mas, falei! Depois, mandei uma carta (eu era boa de carta) ao chefe de Departamento, 
protestando. Gente, expor os professores a isso, pra não pôr uma rosca! Então eu acho que com aquela jogação de pedaços [da mesa] eu conquistei os alunos. Mas, fiquei com medo de oferecer [Sociologia] Rural porque, quando não tinha aluno para fechar a turma, você ficava com a disciplina que sobrava. Outra vez eu fui dar Introdução à Sociologia na Contabilidade. Eu pensei que ia enlouquecer. Pensei mesmo! Aí uma horista trocou comigo porque eu não sou uma pessoa muito polivalente, não. O que eu sei fazer, eu sei. Posso dar [Sociologia] Rural, metodologia, teorias. Introdução à Sociologia, o colegiado de curso não deixava os mais titulados darem, porque tinha muito professor para Introdução à Sociologia. A gente ficava com as cadeiras dos últimos anos. De repente, você, que nunca tinha dado Introdução à Sociologia, tinha que dar a disciplina para a Contabilidade! Eu pensei que ia enlouquecer porque eu não conseguia prender a atenção deles. Por isso que eu troquei. Depois, os alunos ficaram sentidos: "Ninguém ofendeu a professora". Ninguém ofendeu mesmo. Mas, conversavam o tempo todo, eu não conseguia prender a atenção deles. Também a Zuleika logo parou de dar aulas, depois que eu voltei do doutorado, pois assumiu cargos administrativos e o Júlio Wiggers foi para os campi avançados, que ele ia pro Norte, e Sociologia Rural foi ficando pra trás. No mestrado sempre foi um pouco difícil.

Agora, tem uma coisa de bom. Os que vêm fazer Sociologia Rural são filhos de agricultores, eles são convictos. Tanto que eu não perco orientandos. Eles defendem. Eles não chegam sem saber o que querem. Ninguém escolhe Sociologia Rural se não estiver convicto, porque é uma pesquisa difícil. Você tem que ir para o rural, vai a pé... Eu tive uma aluna que fez o TCC de bicicleta. Às vezes precisa carro. Os meus orientandos são convictos. Eu nunca tive montes de orientandos, mas nunca faltou e sempre defendendo. Tanto que uma vez eles fizeram uma média das defesas orientadas por professor e eu estava na média. Eu pensei que estivesse abaixo.

Eu me mantive no rural até hoje. O rural é assim: sobe e desce. De vez em quando está cheio o núcleo que coordeno, como agora. Na época de 1988, Constituição, reforma agrária, tudo aquilo, foi impressionante. Na ANPOCS, não me lembro o ano, fizeram uma avaliação das três áreas. Na primeira ANPOCS em que fui, em 87, foi que a llse descobriu que eu não era nordestina porque eu falei que era de Piracicaba e Águas de São Pedro 
[onde se realizava o evento] era ali perto. Ninguém sabia de onde eu era. Os meus orientadores estavam lá, o Albertino Rodrigues, o Otávio, e um dizia pro outro de quem que eu gostava mais - aquela brincadeira... Então houve uma mesa que fez uma análise das três áreas. A Antropologia, como sempre, tem uma autoestima alta, mas a Sociologia falou dos trabalhos sobre o rural e concluiu que tínhamos "uma Sociologia moderna estudando o arcaico". Então minha amiga Giselia Potengy falou: "Não está certo. Por exemplo, sua tese é sobre integração, tema nada arcaico". Então se viu que muita gente considerava todos os estudos do rural como estudo do arcaico. Vejam, com a Constituição de 88, com a reforma agrária, com a conservadoríssima UDR [União Democrática Ruralista] fazendo barulho sob a liderança do Ronaldo Caiado, com o Movimento dos Trabalhadores Sem Terra, é claro que o rural estava chamando a atenção! Eram fenômenos sociais acontecendo diante dos olhos da gente!

Entrevistadores: Quais foram as suas motivações para seguir na carreira de Ciências Sociais?

Maria Ignez Silveira Paulilo: Eu fiz o vestibular em 1970. Era aquela ditadura, todo o mundo pegando fogo. Meus irmãos mais velhos participavam de movimentos estudantis. Então a gente achava que entrando em Ciências Sociais ia resolver muita coisa. Foi motivação política mesmo. Eu pensava: "O quê que eu vou fazer com Física, Medicina? É Ciências Sociais mesmo!”. Foi uma ilusão da época, mas foi esse o motivo.

Entrevistadores: Quais foram as implicações dessa escolha naquele contexto de ditadura?.

Maria Ignez Silveira Paulilo: Olha, lá pelo meio do curso eu já estava um tanto desesperada. Mas, diziam os professores da época que pelo fim do segundo ano todo aluno entra em crise. Aqui [na UFSC] eu já notei que todo aluno quer mudar de curso na quarta fase. Eu até pensei em ir para a Economia ou outro curso, mas depois fiquei em Ciências Sociais mesmo porque, para ir para a Economia, teria que começar tudo do início. Não é que eu não tive crise durante o curso, mas fiquei. 
Quando terminei é que se desfez mesmo a ilusão. Emprego era difícil, tudo era difícil. Meus pais foram muito compreensivos, mas tanta gente me amolou quando escolhi que graduação fazer, que decidi que tinha que fazer alguma coisa com Ciências Sociais. Eu não queria reconhecer o que os meus antigos professores me diziam: "O que vai ser do seu futuro? Você está estragando a sua vida". Aquelas coisas. Mas eu não sabia o que fazer da vida. Por sorte, na cidade onde moravam meus pais, que é Piracicaba, tinha esse curso de mestrado que fiz.

Eu lembro que apareceu um emprego e a possibilidade desse mestrado, como aluna especial, sem bolsa, sem um tostão furado, nada. Eu lembro que afundei o corredor da casa andando de um lado para o outro, na dúvida se eu ia trabalhar em uma empresa, fora da minha área de formação, ou se eu ia fazer mestrado. Ninguém falou nada, mas quando eu decidi pelo mestrado minha mãe ficou muito feliz. O emprego era na Dedine [Dedine S/A Indústrias de Base], na área de Estatística. Mas eu não queria desistir porque eu ia me sentir muito humilhada. Então, o rural, eu acho que foi meio sem querer. Se tivesse um outro mestrado, acho que eu faria porque eu não sou filha de agricultores como todo mundo pensa. Eu sou do interior, mas filha de agricultores eu nunca fui, e nem neta. Nem tinha nenhuma vivência de mexer com a terra, nem essa coisa de passear no sítio dos avós, não tinha. Mas aí, eu gostei muito.

\section{Entrevistadores: O que te fez fincar pé no mundo rural?}

Maria Ignez Silveira Paulilo: Como eu já era feminista e o feminismo era um fenômeno muito urbano, enquanto o Brasil ainda era muito rural, eu pensei: "Metade das mulheres deste país ninguém escuta". Então, minha dissertação foi sobre a mulher rural. Mas, fiquei um pouco chocada. Na época, nós feministas achávamos que trabalhar era a coisa mais libertadora que havia. Depois que eu descobri, e escrevi isso na minha dissertação, vamos deixar este conceito de liberdade pra lá. Trabalhar dá autonomia com relação à família, com relação ao marido, mas liberdade?! Nessas alturas eu já estava mais realista.

A mulher rural sempre trabalhou. O tema era o trabalho. O feminismo entrou na academia brasileira via Sociologia do Trabalho. Na ANPOCS, entrou no grupo que discutia 
trabalho. Foi aí que o feminismo entrou. Se estudava as mulheres operárias e era um feminismo muito marxista. Porém, como a mulher rural sempre trabalhou, as mulheres estavam tão cansadas, diziam que elas gostavam do trabalho da roça porque, apesar de que o trabalho da roça ser mais difícil, vai sempre para frente, o trabalho de casa é circular: você lava-suja, lava-suja. A minha amostra da pesquisa de mestrado era enorme, eu fiz dezenas de entrevistas. Entrevistei pequenos, médios e grandes produtores, parceiros, assalariados, tudo mulher (a gente não tem modéstia quando é jovem, né? Quase enlouqueci). Mas, o que acontecia? Elas se sentiam muito cansadas e preferiam não ter a roça. Que decepção para as marxistas ingênuas! Elas preferiam ficar só com o trabalho reprodutivo e deixar o produtivo! Daí eu entendi que trabalhavam sem remuneração, o que muda muito as coisas. Eu tinha aquele entusiasmo pelo trabalho considerado produtivo. Fiquei toda decepcionada.

Depois passou essa minha tristeza. Eu tinha ido para a Europa com minha irmã e uma amiga, quando estava fazendo o mestrado, no início de 1976 (mochila nas costas e banho de vez em quando...). Depois fui pela segunda vez e passei para ver o que tinham sobre mulher rural e, na Europa, diziam exatamente isso, que nos anos 1970 as mulheres consideravam o trabalho rural muito duro. Depois, com a diminuição dos filhos e com a tecnologia, foi que elas começaram a se considerar agricultoras e a se valorizar mais. Foi exatamente isso o que eu tinha visto sem entender bem.

Depois, teve o Movimento de Mulheres Agricultoras, no início dos anos 1980. Mas, na década de 70 era muito pesado ser agricultora. O trabalho da mulher sempre foi pesado, mas naquela época ainda eram muitos filhos, pouca tecnologia, era muito pesado. Então elas queriam se livrar de algum pedaço do trabalho. Ninguém achava que mulher podia se livrar do trabalho de casa e dos filhos. Então, se elas queriam trabalhar menos, tinha que ser não ir à roça, ao campo, embora muitas delas dissessem que era o trabalho em que sentiam mais prazer. Aí eu não larguei mais do rural porque eu gostei muito das mulheres. 
Entrevistadores: Você tem uma entrada também junto ao MST, isso foi no mesmo conjunto ou em outro momento?

Maria Ignez Silveira Paulilo: Não, é diferente. Quando eu comecei o doutorado, em 1981, não tinha o "Sem Terra" como conceito, é claro que tinha muito, mas era o "peão". A ideia que se tinha de Santa Catarina é que aqui era só agricultura familiar. Mas eu já estava muito desconfiada de que não era. Então saiu o primeiro trabalho, do César Freysleben Silva, mostrando que havia muito agricultor sem-terra. Quando eu cheguei aqui, eu fui junto com a Zuleika estudar a integração no Oeste e fiquei muito surpresa com tudo aquilo. O pessoal dizia que o integrado era um assalariado sem o INSS. Todos os trabalhos escritos também falavam isso. Agora, eu, vindo do Nordeste, tendo conhecido o Norte, a agricultura do Norte e a agricultura do Nordeste, eu chegava aqui e via aquelas famílias, tudo forte, eu dizia: “Gente, não é a mesma coisa!”. No Nordeste eu havia feito uma pesquisa sobre “moradores”. O morador não é um assalariado - parte do ano ele é, outra parte não. Eu vi o que era não ter terra. Antes de defender o mestrado, eu participei também de uma pesquisa grande no Vale do Ribeira. É uma região pobre de São Paulo, é pobre até hoje. Naquela época eu vi o que era ser "sem terra", o que é a pobreza. Então eu falei: "se vocês chamam todo mundo de assalariado, o assalariado desaparece, não sobra ninguém. A gente tem que fazer a diferença entre quem tem alguma coisa e quem não tem nada". Aí, eu fui estudar a integração e fui muito criticada. Eu falei que tinha que diferenciar entre exploração e miséria.

Porque o que eu tinha visto no Nordeste era miséria mesmo. Eu andei naqueles interiores todos e o que se via no Nordeste daquela época, o poder do fazendeiro, uma mulher me dizia: "É Deus no céu e o Seu Fulano [o fazendeiro] aqui na terra. Se a gente cai num fracasso de ser preso, ele vai lá e tira". Eu consegui entrevistar um senhor de engenho só porque estava junto com a sobrinha dele que era minha aluna. Depois eu perdi essa entrevista (eu guardo muito as coisas, mas não lembro onde ficou essa entrevista) e lembro do Afrânio Garcia falando assim: "Você perdeu um documento histórico!” - Que era a minha própria entrevista com dois senhores de engenho. Um deles falava assim: "O morador vem aqui, eu deixo ele lá fora rodando o chapéu. Uma hora depois é que eu vou falar com ele, pra ele entender quem é que manda”. Outro falou: "Tá 
faltando a terceira guerra mundial pra endireitar este país”. Eu sabia o que era isso. Então, quando eu cheguei aqui eu falei: “Não dá para chamar tudo da mesma coisa. Tem que diferenciar exploração de miséria". O integrado, ele é explorado pela agroindústria, não estou dizendo que não. Agora, ele não está na miséria. Ele tem terra. A importância de ter um pedaço de terra, no Norte e no Nordeste, é tão grande, que eu não entendia chamar todo mundo igual.

Mas eu fui criticada por isso. O Gnaccarini [José Cesar Gnaccarini], da USP, escreveu que as ideias burguesas entravam até no cérebro dos pesquisadores - como foi, segundo ele, o meu caso. Eu não tinha lido [a crítica] ainda quando veio todo mundo me contar que o Graziano [José Graziano da Silva] tinha me defendido. Aí é que eu fui ler o que ele falava de mim. Por que eu queria diferenciar? É que no campo eu só via peão, mas o peão não existia, não se falava dele. Eu escrevi na minha tese que eles faziam parte da paisagem, ninguém via. Quando eu perguntava: "Quando você tem que passar veneno e fazer cerca?" O cara dizia pra mim: “Eu contrato um peão. O trabalho ruim, passar veneno, eu tenho um negrão que passa veneno”. Aí eu escrevi na minha tese: “Eles fazem parte da paisagem". E ficava todo mundo falando que aqui era só agricultura familiar. Então, eu prometi a mim mesma que quando eu acabasse a tese, que nunca acabava, porque eu levei seis anos para fazer, eu prometi a mim mesma que eu falaria desses peões. Quando foi em 84, eu já tinha feito o meu campo, estoura o Movimento dos Trabalhadores Sem Terra. Quando eu consegui acabar a tese, em 1987 mesmo, eu fiz um projeto para estudar os Sem Terra - que agora já era Sem Terra mesmo. Então me perguntaram: "Só no Paraná já tem mais de 40 dissertações sobre os sem-terra, por que você quer estudar isso?” Eu falei: “Porque é uma dívida da minha tese”.

Eu não conseguia financiamento de jeito nenhum. Aí, a ANPOCS me deu um dinheirinho e o pessoal que trabalhava no assentamento de Putinga, o Valério Turnes e outros, esse povo me ajudou e eu fui parar lá no assentamento de Putinga, em Matos Costa, SC. Não dava pra ir mais longe porque não tinha um tostão furado. Fui fazendo essa pesquisa e, quando chegou em 93, fui fazer o concurso para Titular. Foi quando eu escrevi o livro "Terra à vista... E ao longe" [Editora da UFSC, 1996]. Eu queria mostrar como eles viam a terra. Que eles viam a terra mas estava sempre longe. O eixo da 
pesquisa mudou. Tanto que o único pedaço sobre os sem-terra, os antes invisíveis peões, é o último capítulo do livro, onde falo do assentamento de Putinga. Eu não consegui ir mais longe sem um tostão.

Mas, Putinga era muito interessante. Foram comigo a Alícia Castels, o John Kleba e a Elisete Schwade. A gente usava o carro da Epagri. Chegou lá, o carro não funcionava, um fusca nojento. Eu nunca fui boa de direção. Quem dirigia era a Alícia e o John Kleba. Como atrasou a pesquisa, nós só tínhamos uma semana para ficar em campo porque a gente tinha que dar aulas. Aqueles campos longos de pesquisa de antigamente, como é que a gente podia fazer dando aula? Um dia inteiro o carro ficou na oficina e a gente queria que rendesse. Daí a pouco armou um temporal... O Valério estava lá. Eu falei: “A gente vai ficar”. O Valério falou: “Vocês podem ficar, mas eu vou embora”. Eu conhecia o Valério. Eu já tinha visto o Valério dirigir o carro em cada circunstância! Se ele não achava seguro ficar lá, melhor sair. A gente dirigia com corrente na roda. Então, o Valério colocou as correntes nos pneus, amarrou com pedaços de borracha de câmara de pneu e se mandou. E lá fomos nós embora também. Quando chegamos no asfalto, quem é que desamarrava o amarrado do Valério? Peguei meu canivete na bolsa e cortamos tudo. Então, temos esses episódios do campo.

Foi assim que eu escrevi "Terra à vista... e ao longe", mas nessas alturas ninguém me criticou, não. Foi um sucesso. O livro teve duas edições esgotadas. Porque tudo tinha mudado, já era Sem Terra, a categoria já existia. Já em 1984, quando eu ainda dava aula de Sociologia Rural pra graduação e tudo, os textos de antes de 1984 não serviam mais, porque ninguém viu nada. A gente só discutia a penetração do capitalismo no campo. A gente achava que, se tinha movimento, ia ser por salário - porque teve também por $13^{\circ} \mathrm{e}$ tudo. Agora, como eu era pesquisadora de campo, estava no olho do furacão, eu via aquilo e dizia: "Gente, isto não é assalariamento disfarçado", como dizia o Caio Prado Júnior, “isto é outra coisa que não tem nome. Não tem nome mas é uma coisa muito forte". Aí, foi e ficou Sem Terra mesmo porque a academia não teve nem tempo de elaborar. Como é que Marx falava? Exército industrial de reserva? A gente tentava fazer de tudo com aquilo, mas não dava certo. Então, não sei o que deu no mundo, porque a gente queria pensar em modo de produção, só modo de produção stricto sensu, mas não 
achava, não conseguia encaixar o rural. Fazia o diabo, mas a gente tentava! Aí, começaram a aparecer uns textos. Quando começou? Porque o estruturalismo, nos anos 70, foi fortíssimo. A gente achava que se não fosse estruturalista, a gente não era nada. De repente, começou a crítica. Todos os marxistas que a gente conhecia escreveram “estrutura e formação social”, criaram um novo conceito pra dar conta de tudo o que estava acontecendo. O Fernando Henrique, o Laclau [Ernesto Laclau], o Stavenhagen [Rodolfo Stavenhagen], o Stavenhagen não foi com esse título, mas falando outras coisas. Porque pra gente era difícil pensar com os conceitos que a gente tinha. Então, foi melhorando. Quem pensava o rural começou a pensar essas coisas.

O Graziano [José Graziano da Silva] foi muito importante, só que ele era economista. Então, ele tinha um jeito de pensar que me ajudava, mas não em tudo. A Nazareth [Maria de Nazareth Baudel Wanderley] escreveu em 1979 aquele texto "Todos são trabalhadores para o capital" e ela nunca publicou com este nome [acabou publicando, em 1985, com o título “O camponês: um trabalhador para o capital”] e depois ela foi uma das que mais escreveu sobre o campesinato. Mas o pessoal não deixava ela em paz. A Nazareth, eu acho um gênio. Você, conversando com ela, quando está no debate, ela saca cada coisa! Ela tem uma capacidade de sacar impressionante. O José de Souza Martins, que quando quer ser maldoso ele é, ele sempre escreve: “José Graziano da Silva, agrônomo...”. Da Nazareth, ele dizia: “ela nunca publicou... mas não se importa que citem". Ele, quando queria, era ranheta, uma coisa que preste! Todo mundo adorava o José de Souza Martins, eu também, mas eu o conhecia desde 1974, 1975, de São Paulo, era amigo do Oriowaldo Queda e eu ia assistir defesas quando ele estava na banca, às vezes de carona com o Queda. Uma vez, ele chegou aqui em Florianópolis e falou: "Sabe o que está estragando a pós-graduação da UFSC? As mulheres. Porque elas entram pra fazer mestrado, mas, ficam cuidando da família". Eu, feministíssima, subi nas tamancas! Não adiantou reagir, ele passava batido! Ele tinha vindo para uma banca e estava impossível naquele dia. Me fizeram ir jantar com ele, junto com o Viola e a llse, porque eu era coordenadora da pós. Ninguém o conhecia pessoalmente e não entendiam a minha resistência em fazer-lhe companhia. O Martins, já no caminho, começou a falar de linchamento, que arrancavam os olhos dos massacrados com colheres. Ele estava 
escrevendo sobre linchamento. Uma hora eu falei pra ele: "Ou você para ou eu vomito! Porque eu não vou conseguir comer”. Depois, contou que tinha entrado no Mosteiro de São Bento [cidade de São Paulo]. Naquela época, mulher não podia entrar na biblioteca do Mosteiro, por incrível que pareça, e isso me deixava demente! Eu estava tentando achar um homem que pudesse entrar lá e pesquisar para mim, porque eu queria as bulas papais que falassem sobre os índios brasileiros, se, afinal, para a Igreja, tinham alma ou não? No fim, o Jean Hébette [1925-2016], aquele santo, que foi padre na Amazônia, me mandou um artigo sobre as bulas papais, discutindo se índio tinha alma ou não. Ninguém sabia [das bulas]. Eu escrevi para a Alcida Rita Ramos, que é antropóloga indigenista, e ela me falou: "Se você descobrir, me manda". Tanto que eu mandei e ela disse que usou em sala de aula. Mandei pra todo mundo. Como eu queria essas bulas papais e os monges no meio do caminho! Como se não bastasse, o José de Souza Martins começou a defender a castidade deles, que ser casto ajudava a pensar (?!). Ele casado, o Viola casado, a Ilse casada, e eu viúva. Puta!, porque eu não aceitava ser viúva. Aí eu falei pra ele: "Eu não melhorei nada. Aliás, só estragou o meu pensamento”. Como sempre, ele passou batido, nem respondeu. Uma vez eu cheguei num encontro da ANPOCS e falei: "Eu não estou reconhecendo aquele ali", que era o Martins, ele tinha engordado. O Octávio lanni falou: “É o José de Souza Martins”. Eu disse: “Deus me livre! Eu não quero sentar perto dele”. O Octávio lanni falou: “Então, vem cá e se esconde atrás de mim”. Eu estou contando essas estórias pra mostrar como eram as coisas, mesmo entre os grandes pensadores homens, porque ninguém pode negar a imensa contribuição intelectual do Martins. Agora, escutar feminista e levar a sério estava fora de cogitação.

Mas, você perguntou sobre o rural. Então, quando escrevi "Terra à vista... e ao longe", eu não esperava o resultado. Porque a minha tese foi criticada. Virou livro, mas eu escutei muita coisa. Mas ali o Otávio [Otávio Velho] foi firme na defesa. Ela foi criticada, ele foi firme na defesa e depois fez o prefácio. Porque precisava coragem pra fazer o prefácio. De repente, o mundo mudou. Quando eu escrevo “Terra à vista... e ao longe”, já estavam os Sem Terra aí com tudo.

A minha incursão nos Sem Terra foi pequena. Foi isso. Porque eu voltei ao gênero. O meu primeiro livro não foi de gênero e o meu segundo livro também não foi, mas eu 
sou feminista há muito tempo, eu tinha que trabalhar gênero. Agora, a Sociologia Rural é muito machista e o feminismo é muito urbano. Então, eu não achava muito fácil, não. Eu tinha que ter umas parceiras que me ajudassem. Me ajudava a Carmen Deere. Uma vez, a Joana [Joana Maria Pedro] me perguntou: “Ignez, quando você era feminista, o que que você lia lá na década de 70?" Eu lia a Carmen Deere e a famosa, todo mundo falava dela, Ester Boserup, que escrevia sobre a África - foi traduzida em 1970. A Carmen Deere era a salvação da lavoura, embora eu tenha discordado dela em um artigo (olha, que metideza!).

Alguns pensadores queriam flexibilizar os conceitos, os mais ortodoxos não aceitavam e a gente de permeio. O Francisco Sá Júnior escreveu que a agricultura familiar fornecia mais valia. O Hoffmann dizia: “Mais valia na circulação, não. Mais valia é só na produção". Tanto que eu peguei aquela discussão feminista forte. Elas não lembram, mas eu lembro. Era a Heleyeth Safiotti e a Eva Alterman Blay. Eu estava na SBPC de 1975, em São Paulo. A Eva e outras defendiam que a mulher fornecia, sim, mais valia através do trabalho doméstico, porque esse trabalho permitia que o salário do marido fosse menor, porque ela trabalhava de graça fazendo o dinheiro "render". A Heleyeth dizia: "De jeito nenhum!”. A Heleyeth era muito ortodoxa: “mais valia só na produção. A empregada doméstica não pode produzi-la". E eu peguei toda essa discussão do trabalho doméstico. Então, me dá um pouco de saudades de trabalhar com "mulher”, hoje só se fala de "gênero". Eu fui na minha primeira ANPOCS, em 87, que foi um susto quando aqui descobriram que eu não era nordestina, que eu tinha feito mestrado em São Paulo, que eu conhecia os paulistas tudo. Parece que foi a revelação para o pessoal daqui de quem eu era. Porque o pessoal que chegou não me conhecia. Enquanto eu fiquei no Rio contrataram muita gente. Quando eu cheguei [do doutorado] tinha mudado o mestrado, era outro. Eu fui no grupo feminista, no grupo da Heleyeth, ela que me convidou. Tinha colegas que achavam que nossa discussão sobre gênero era coisa de "baixo nível", indigna da ANPOCS.

Nós feministas tínhamos, moralmente, muita dificuldade de ter empregada doméstica, durante muito tempo eu não tive, porque éramos contra a ideia "da mulher explorando outra mulher". Lembro-me de uma declaração da Marilena Chauí sobre isso 
na época. Era muito difícil. No Nordeste, o trabalho de empregada é a única coisa que muitas poderiam fazer. O pessoal implorava para trabalhar para a gente porque assinávamos a carteira de trabalho. No fim, eu tive uma empregada nordestina muito divertida, cangaceira. Porque eu pensei "entre ela não ter emprego e eu ficar com as minhas convicções...”. Quando me mudei, ela falou pra mim: “Depois que eu trabalhei pra senhora eu não vou trabalhar pra mais ninguém". Porque eu a respeitava. Ela era muito despachada, andava com uma tesoura presa no corpo para quem mexesse com ela, algum homem atrevido. Bem, de repente, estávamos discutindo no grupo da ANPOCS a profissionalização da empregada doméstica como uma solução. Eu não aguentei, sentei sozinha num sofá que tinha no corredor e me pus a dar risada sem parar. Aí parou perto de mim alguém que eu conhecia, uma mulher, e perguntou: “O que foi que aconteceu?" Eu falei: "Pois é, a gente não aguenta mesmo sem empregada doméstica. A gente não queria, mas agora achou uma solução que é profissionalizar. Porque dar conta de trabalhar e do serviço de casa, a gente não dá mesmo”. Ela respondeu: “Ai, meu Deus! Como eu te entendo!". Agora, vai explicar isso para os homens! A gente discutia nosso cotidiano. Não era fácil, grupo de feministas era "grupo de baixo nível”. Você acha? Foi revolucionário as feministas considerarem que "o pessoal é político".

Entrevistadora: Você acredita que há uma crise envolvendo os estudos rurais no Brasil ou em Santa Catarina?

Maria Ignez Silveira Paulilo: Olha, Santa Catarina, embora seja um estado muito rural e se orgulhe disso, de sua agricultura familiar, desde que cheguei aqui meu departamento nunca privilegiou esta área de estudo. Só Freud explica, não sei te explicar. O que eu acho que aconteceu, na quebra desses paradigmas todos, é que há uma atração muito grande por certas linhas novas, que são apaixonantes. Mas são muito teóricas. O que eu acho, por exemplo, do mestrado aqui, agora, é que o pessoal é muito teórico. Não acho ruim. Mas, eu sempre fui de campo. Por exemplo, o Howard Becker, aquele pianista/sociólogo fantástico, é outro que me ajudou muito. Eu sou de campo e ele também, entendeu? Eu lembro que eu brincava com Luzinete [Luzinete Simões Minella], que é uma ótima pesquisadora de campo: “Nós pesquisadores de campo somos que nem médico legista 
no meio dos médicos. Só serve pra abrir morto, porque não presta pra abrir vivo e curar, sabe?".

Então, o que eu notava era um pouco isso. O rural, por exemplo. Os grandes pensadores, antigamente, não tinham essa diferença. Caio Prado Junior ou Celso Furtado pensavam tudo junto. O José de Souza Martins começou seus trabalhos pesquisando o rural. Por que é que eu não fui para Antropologia quando as pós-graduações e, depois, os departamentos se separaram? Porque a Antropologia daqui era muito urbana, embora conservasse uma importante tradição indigenista. Sociedades indígenas e sociedades camponesas sempre foram vertentes tradicionais da Antropologia. Meu doutorado no Museu foi na área de concentração "Campesinato", mas aqui os estudos camponeses tinham ficado um tanto de lado na Antropologia também. Agora tem professores interessantes dessa área por lá. Em bancas onde o trabalho defendido versava sobre o rural, eu frequentemente era convidada a participar porque não tinha muita gente. Agora não tem mais ninguém, porque eu já sou aposentada.

Em relação ao Brasil, até eu não acho tanto porque tem bons autores. Eu compro os livros e leio. Vou ser injusta se eu citar, porque com certeza não vou lembrar agora de muitos nomes. O pessoal lá do Rio Grande do Sul é forte no rural, o de Chapecó também. Mas, o que é que aconteceu? A Sociologia no rural sempre teve uma ênfase mais teórica no Brasil, por isso, também, é que eu fui para a Antropologia. A Antropologia nunca teve vergonha de fazer pesquisa de campo. Na década de 1980, com a valorização dos movimentos sociais e da pesquisa-ação, houve uma valorização grande da pesquisa empírica na Sociologia, mas não era raro termos uma grande discussão teórica primeiro e um capítulo pequeno com os dados de campo confirmando a teoria escolhida. Acho que poucos sociólogos brasileiros afirmariam, como o faz Howard Becker: "eu sou um pesquisador de campo e sempre fui". Então, eu acho que a Sociologia daqui, de Santa Catarina, do Brasil, é muito teórica, valoriza muito a teoria. Claro que sem teoria não se faz pesquisa, mas sem bons procedimentos de campo também não. Quero me explicar melhor. Os mestrandos e doutorandos fazem muita pesquisa empírica, mas parece que dão menos importância ao preparar essa parte da dissertação ou tese. Cuidar da amostragem tem a ver com a representatividade das conclusões. Pode-se querer 
representatividade ou não. Lembro-me, agora, do Florestan Fernandes falando de se estudar o "tipo extremo" no seu livro “Os fundamentos empíricos da explicação sociológica", que estudei na graduação. Para muitos alunos, a amostragem tem que ser matemática, mesmo que seja aquela bobagem de se selecionar $10 \%$ do universo. Como dizia o Hoffman: “pode ser 9,96\%, 8,75\%...”. Não tem um número “cabalístico”, depende do que se quer. Também pode-se garantir a representatividade, se é isso que se quer, qualitativamente. Citando de novo o Becker (sou fã mesmo), não há tanta diferença assim na lógica das pesquisas quantitativas e qualitativas como querem os detratores de cada uma delas. O que não vale é escolher um número de entrevistados, de comunidades, de famílias, de qualquer coisa que não representa o universo todo e concluir em nível desse universo. Melhor assumir os limites da pesquisa.

O problema, nas bancas, é que nem sempre o orientador também tem formação nessa área. Mas o pessoal fazer questão de ir para campo, eu acho bom. O campo “sacode" a gente! Se a gente desistir... Se a gente tem uma semana, a gente vai uma semana, prepara bem o campo antes, mas fala a verdade. Não vai falar que fez Pesquisa Ação, Pesquisa Participante, Observação Participante, Etnografia, porque a gente não fez. A gente fala a verdade, mas faz, não perde a oportunidade de conviver com as pessoas. Um bom pesquisador de campo tem que ter um bom "repertório" de procedimentos, técnicas, "soluções emergenciais". Se não se pode adquirir isso participando em muitas investigações reais enquanto estudante, como aconteceu comigo e outros da minha geração que "ajudavam" os professores a concluir suas dissertações e teses, discutir experiências alheias também é bom. Acho interessante a última reforma do currículo de nossa graduação em Ciências Sociais ter incluído as disciplinas Práticas de Pesquisa I e II, nas quais os alunos trabalham dentro dos núcleos de pesquisa existentes e ativos. 
Entrevistadores: Em relação às categorias teóricas que estão em uso para pensar o mundo rural: você tem algum balanço disto?

Maria Ignez Silveira Paulilo: Eu acho que se faz um esforço, nós estamos sempre fazendo um esforço. Tem um pessoal, por exemplo, todo pensando o rural. Você concordando ou não, eles estão pensando o rural. O gozado é que nos países da Europa e nos Estados Unidos, ninguém se abala. É só Sociologia Rural mesmo que se diz, não inventam outros nomes. É Sociologia Rural, é campesinato. Eles tiveram a Idade Média com seus camponeses... Diferente de nós, cuja agricultura familiar já nasceu com a expansão mercantil do Velho Mundo. Talvez, por isso, nem todo mundo aceitou o termo. Nos países ditos desenvolvidos ninguém quer mudar o rural de nome. Até o último livro de um autor que eu gosto muito, o James Scott, campesinista, ele escreveu sobre mudança. Tentou fazer umas coisas diferentes. Eu gosto do livro dele. Mas ele escreve sobre o campesinato da Ásia. Eu acho que no Brasil a gente está sempre um pouco desconfiado com os conceitos. O José Vicente Tavares dos Santos, na ANPOCS de 1990, tentou mudar para algo como Sociologia das Sociedades Agrárias. Tentou mudar mas não colou. Foi tão divertida essa ANPOCS! Agora, o Sérgio Schneider está com uma outra proposta, eles querem estudar sistemas alimentares. Algo como Sociologia dos Sistemas Alimentares. Nos outros países fala-se em rural e todo mundo sabe do que a gente está falando. Ninguém se incomoda. Os congressos em que eu vou, América Latina, Europa, fala-se em rural o tempo todo. Eu fui em muitos congressos na América Latina, agora estou meio cansada. Mas na Europa também. Eu fui em congressos em Portugal e Espanha, você fala em rural numa boa. Eu também estive na África, Moçambique e Cabo Verde, mas não tive tempo de me aprofundar. Eles falam muito de mulheres rurais porque elas trabalham nas lavouras mesmo, com a terra. Eu tenho os trabalhos das moçambicanas, os trabalhos das cabo-verdianas. Quem faz Sociologia Rural bem é a França.

A Sociologia Rural no Brasil sempre foi francesa. Maria Isaura Pereira de Queirós, todo mundo, estudava na França. Quando eu estava no Museu, todo mundo fez pósdoutorado com Bourdieu. Eu fui me meter na Inglaterra, primeiro porque o meu orientador, o Otávio, tinha feito pós-doc na Inglaterra e, em segundo, porque eu só sabia falar inglês, francês não tinha jeito. E fui. Mas eu queria mesmo ir. Eu conhecia os 
trabalhos daquele grupo interdisciplinar famoso de pesquisadores de New Castle, Inglaterra: Terry Marsden, Jonathan Murdoch, Philip Lowe e acho que mais três. Eu me impressionei muito, gostei da linha deles, do que eles escreviam. Eram seis, cada um de uma formação. Eu tenho dois livros deles. Na Inglaterra eles publicam pouquinho [tiragens pequenas]. Daí você quer e tem que fazer fotocópia.

Eu fui até a saída da Inglaterra com a França, com um medo medonho, pegando trens sem saber bem o que fazer, só pra conhecer a Ruth Gasson. Aconteceu o seguinte na Inglaterra: eu não sou uma pessoa desinibidíssima assim e não nasci para grandes aventuras. As aventuras acontecem não sei por quê. Que eu goste e procure, não. Lugar diferente, eu vou. Mas que eu me sinta à vontade... Eu sou muito caipira de interior. Aí, o que que aconteceu. Eu fui pra Inglaterra assim, muito desarvorada. O meu supervisor foi o Anthony Hall, que fala o português do Brasil bem mesmo. Mas eles acham que brasileiro é atrevido. Então, eles não se preocupam com os estudantes brasileiros. Acham que a gente vai meter a cara. Eu fui com um projeto sobre feminismo. Eu escrevia para as pesquisadoras inglesas que pesquisavam América Latina. Só Ruth Gasson me atendeu, ninguém mais. Elas marcavam, desmarcavam, marcavam de novo, desmarcavam a segunda vez e eu não tinha mais coragem de remarcar. Quando eu falei com a Ruth Gasson ela falou: “Não se preocupe”. Esqueci a universidade dela, era bem longe.

As feministas de Londres têm preconceito contra mim também. Então, eu não conseguia me encontrar com elas. O meu supervisor eu via pouco, porque não era obrigação dele me pajear. Eu fiz disciplinas por minha conta. Uma das professoras era indiana. la a palestras para poder ouvir sobre rural e feminismo... Metodologia de Pesquisa eu fiz com um professor ótimo, George Gaskell, que depois o livro, em parceria com Martin Bauer, foi traduzido [Martin W. Bauer e George Gaskell] para o português. Ê, livro bom! Eu fui aluna dele porque eu me metia nos cursos mas, assim, aqueles cursos pra 50 alunos. Eu acho que se eu fosse invisível na Inglaterra, era igualzinho. Quando o Prof. John Wilkinson, inglês, fez a carta de recomendação, ele falou: "Eu faço a carta de recomendação, mas só se você quiser ficar ao léu por lá, porque ninguém vai te dar atenção". Dito e feito. Só me deram um caixotinho assim, que era pra eu pôr as minhas coisas, mas tava cheio de lixo. Não tive direito a computador, a sala, nada! 
Eu não era recém-formada, tanto que eles não me aceitaram como pós-doutorado. Me aceitaram como Academic Researcher, que é um pouco acima. Porque, pra eles, eu tinha trabalho publicado e tudo, eu não era uma pós-doutoranda. Eu pus no meu currículo “Pós-doutorado", porque eu saí com bolsa da CAPES pra fazer pós-doutorado. Mas eu tinha uns privilégios, que não eram tão privilégios assim, que era poder almoçar no restaurante dos professores (comida inglesa de universidade, todo mundo sabe, não é muito boa, pesada). Lá era tudo muito hierárquico. Então, os meus colegas pósdoutorandos diziam que eu podia convidar outras pessoas, eles queriam ir. Mas a gente não ganha nada. Eu era considerada do staff, eu podia entrar no banheiro exclusivo do staff e ir nesse restaurante. Mas, se eu fosse transparente dava no mesmo.

Então, eu ficava me metendo nos cursos, assistindo. Agora, tem uma coisa: a pessoa acabou de falar, ela publica. Eu tinha a mania do Brasil de "arrancar" o trabalho da mão das pessoas. O Moacir Palmeira é o próprio. Ele fala, fala as coisas, mas até ele publicar... Eu estava acostumada a arrancar. Quando eles faziam palestras, xerocar as folhas. A gente fazia e faz cada coisa! Aquele economista, o Guilherme Delgado, fez uma palestra. Eu catei o pendrive dele. Eu não sei fazer essas coisas, pedi ajuda pra todo mundo. Todo mundo copiou. A gente estava acostumada assim. Então, eu achava que lá era igual. Mas, não. Depois eu percebi que as pessoas publicavam muito. Que se podia conhecer as pessoas lendo. Eu não precisava entrevistar. Aí eu sosseguei. Mas, quando eu fui embora, eu pedi para o meu supervisor, Anthony Hall, fazer uma carta (eles não sabem fazer essas coisas) para o Brasil, sobre o que eu fiz. Mas ele falou: "Você não apresentou palestra, você não fez nada?” Aí, a culpa ainda era minha!. "Porque você tinha que ter insistido". Eu falei pra ele: “Mas eu marco uma vez, a pessoa desmarca. Marco uma segunda vez, a pessoa desmarca, eu não tenho coragem de marcar uma terceira". Ele falou: “Errado! Você tinha que insistir. Você tinha que marcar a terceira”. Mas, não. A imagem do brasileiro lá é essa. O brasileiro se vira! Ele é cara de pau, ele se vira! Quando ele viu que eu não me virei, se espantou e se irritou um pouco... Foi um ano perdido em termos de currículo. Sim, porque ninguém me convidou para dar uma palestra.

Agora também eu não gostava do meu inglês, tinha vergonha. Mas eu já fiz palestra em inglês. Eu mando traduzir, ensaio e leio. Minha filha tem um inglês perfeito, 
britânico, shakespeariano. Quando ela morou lá comigo, tinha aquele inglês da adolescência. Depois eu a mandei estudar lá de novo, o professor era shakespeariano e ela pegou o jeito. Minha filha lia, gravava a fita (nada de celulares ainda...), e eu ficava ensaiando. Não teve problema. Eu falei inglês em Amsterdam, eu dizia: “Dá pra entender?" Diziam que dava. Eu também passava cópia para as pessoas, mas eles achavam um exagero. Depois, uma russa e um japonês falaram em inglês e eu não entendi nada. Eu não tenho bom ouvido, mas franceses falando inglês é uma beleza. Por que não é sua língua mãe e eles têm vogais como a gente. Os ingleses, mesmo os estadunidenses, se eu ficasse perto, olhando a boca, eu entendia porque estudei inglês minha vida inteira. Mas, quando a russa falou e o japonês falou, eu pensei: "Acho que a minha não estava tão ruim assim, não". Então, foi timidez. Porque se alguém me convidasse eu daria um jeito. Eu faria tradução, eu leria. Eu consigo entender as perguntas. Mas, ninguém me convidou. Eu ia meter a cara? Eu achei engraçado que mesmo as feministas que estudavam a América Latina, e eu já sendo pesquisadora, ninguém quis conversar comigo.

Na Inglaterra é que eu percebi uma coisa que depois se acentuou. A América Latina é só a América Hispânica no exterior. Quando eu era jovem, se dizia muito que a gente estava de costas para a América Latina, que o Brasil só mirava a Europa. Não estava totalmente errado, mas essa via tem duas mãos. Comprei livros em outros países sobre a América Latina quem nem citavam o Brasil. Outra coisa que eu notei: o português não é facilmente compreensível pelos hispano-falantes e um linguista belga me explicou uma vez os porquês (são mais de um), mas faz muito tempo e tenho medo de falar besteira. Um dos motivos eu me lembro: o português tem sons que o espanhol não tem. As vogais "a", "e" e "o" nós pronunciamos às vezes de maneira aberta e, outras, de maneira fechada. O som "ão" é só nosso. O português, em termos de sons, segundo ele (não me culpem) "contém" o espanhol. Ele tentou me explicar também diferenças entre línguas silábicas e não silábicas, mas confesso que não entendi. Hugo Ratier, antropólogo argentino, amigo meu de décadas e décadas, falante de um português impecável, fica admirado porque, antes de publicar um artigo ou livro, eu pago para um profissional rever todo o português, apesar de eu mesma corrigir a redação das teses e dissertações de 
meus alunos. Ele disse que isso não acontece na Argentina com professores do meu nível. Meu professor de português, durante todo o ensino médio, foi seu Evaristo Pereira, formado em Coimbra. Era exigente! Até outro dia me mandaram a poesia: "Última flor do Lácio, inculta e bela. És, a um tempo, esplendor e sepultura...” [Olavo Bilac, poema “Língua Portuguesa"]. Me deu vontade de mandar, por brincadeira, para as minhas amigas que falam espanhol e se queixam do português. Eu estive num congresso em 2018 em Montevidéu. Éramos quatro coordenadoras do GT: nicaraguense, mexicana, uruguaia e brasileira (eu). A gente se revezou duas a duas. Um dia não era minha vez e não pude mesmo estar presente. Houve um debate furioso em português, mas as coordenadoras não conseguiram entender do que se tratava para fazermos o relatório final.

Acho que o português é uma língua rude mesmo! E pior, empolada. A minha avó era espanhola mas não falava espanhol porque veio pro Brasil pequena, falava português sem sotaque. Mas a gente cantava em espanhol até arrebentar. E teve uma época que o tango teve muita importância nas rádios. Cantava-se em espanhol, mas também se traduzia muito. Minha mãe, que tocava bandolim (tocou piano quando jovem), adorava cantar o tango. Às vezes, parte da música era em espanhol e parte em português. Eu não lembro quando comecei a entender o espanhol falado e escrito. Falar e escrever, isso nunca fiz, mas entender...

Além da barreira da língua, eu percebi que os países da América Latina que atraíam mais a atenção das pesquisadoras inglesas eram os que tinham população indígenas herdeiras de grandes civilizações: Peru, Bolívia, México. Fiquei surpresa quando a Ruth Gasson, na Inglaterra, me perguntou se eu estudava o Terceiro Mundo. Eu respondi que era brasileira e estudava o Brasil. Então ela disse: “Brasil não é terceiro mundo!”. Eu levei um susto tão grande! Eu não sabia o que responder. A Carmen Deere é norte-americana, mas a mãe é porto-riquenha. Espanhol pra ela é língua materna e ela entende português muito bem, mas disse que isso não é muito comum. Falou que o português antigo e o espanhol são muito parecidos. É verdade, basta a gente ver as letras das cantigas dos trovadores medievais de Portugal e Espanha. A Carmen me contou que ela conseguiu traduzir um texto escrito em espanhol gótico justamente porque conhecia o português. Nesse texto se usava o "f” em lugar do "h", por exemplo, "faço" ao invés de "hago". Ela 
traduziu tudo, sofreu pra burro, depois apareceu o texto traduzido! Porque letra gótica é fogo! Esses documentos antigos, que as revistas de história brincam reproduzindo para ver se a gente consegue ler, não entendo nada! Então, eu percebi que o diálogo entre o Brasil e o restante da América latina é difícil mesmo.

Quem está fazendo isso é a Maria Luísa Femenias, argentina, em seus livros sobre os feminismos latino-americanos. Ela inclui trabalhos sobre o Brasil. Mas é uma das poucas. Depois, começou a aparecer um pouco mais o Brasil. Eu não sei dizer quando, mas eu acho que é muito recente. Gozado [risos], a gente foi colonizado por Portugal, mas você não acha livros de feministas portuguesas ou de outros países que falam português nas livrarias daqui, de jeito nenhum. Mas quando você vai para países da América Hispânica, por exemplo, para a Argentina ou Uruguai, as livrarias têm exemplares da Espanha, do Peru, do México e por aí vai... Eu gosto muito do feminismo espanhol. Quando vou para a Espanha, volto carregada de livros. Porque eu acho que o feminismo espanhol conservou essa coisa de falar da desigualdade econômica, de publicar dados sobre grandes disparidades entre grupos sociais, da pobreza de algumas áreas rurais. Porque o feminismo brasileiro ficou muito urbano e entrou na virada linguística com tudo. Não sou contra essa virada, também gosto. Você ver que tudo é discurso, isso é muito importante, mas achar que todos os discursos se equivalem em termos de ciência, acho absurdo. De repente, não se fala em desigualdade, é só diversidade de sexo ou reprodução. Reconhecimento e reprodução. Quando eu li que a Carmen Deere também sentia falta, no feminismo, de estudos sobre as diferenças entre propriedade e renda, me vi compreendida. Coisas que eu gosto de estudar, entende? E o feminismo espanhol fala disso, então eu gosto. Mesmo das autoras mais filosóficas. Leio a Célia Amorós, a Maria José Guerra Palmero, a Alícia Puleo, a Nuria Varela, a María Ángeles Duran, a Rosa María Rodrigues Magda, a Cristina Carrasco... Eu gosto demais dos livros delas. Gosto também quando falam que o lluminismo não é para ser jogado fora, no lixo, como a gente tá fazendo. Elas falam que o feminismo é o filho não querido, acho que é essa a expressão em espanhol, o filho rejeitado, mas é filho do lluminismo. Se a gente não tiver umas bandeiras universais, como é que a gente briga, né? Não dá para jogar o iluminismo no lixo, né. 
Entrevistadores: Eu queria que você retomasse a questão das categorias teóricas, especificamente sobre uma categoria que surgiu há algumas décadas e que acho que as Ciências Sociais abandonaram, não tenho certeza, mas que ainda é utilizada em outras áreas, que é a categoria de "novo rural". O que você tem a falar sobre isso?

Maria lgnez Silveira Paulilo: Sobre o novo rural... É que no Brasil, de repente, a gente acha que está acontecendo no Brasil inteiro, mas não está. Foi quando saiu, por exemplo, a pluriatividade. Eu gosto da categoria porque, inclusive, tem um texto muito bonito que eu dei para meus alunos lerem, da Maria José Carneiro, que fez doutorado na França com o Godelier [Maurice Godelier]. Ela tem um livro, que é sua tese de doutorado, e tem um capítulo sobre pluriatividade em que ela estabelece limites para o uso do termo. Se chamarmos tudo pelo mesmo nome, o conceito perde a utilidade. Isso aconteceu com a ideia de agricultor part time... Nem foi traduzido o termo para "tempo parcial", ficou part time mesmo. Era uma ideia de que esse agricultor estava com o pé na cidade. Eu acho que quem sacou bem foi a Nazareth Wanderley num debate que a gente estava fazendo sobre os sem terra. Ela falou: "não, as pessoas vão para outro trabalho para continuar agricultor, para continuar produtor. E a gente vê como um crime, quase, os assentados fazerem isso". Aquele trabalho do José Graziano... Eu gosto muito dos trabalhos dele. Mas quando afirma que os agricultores estavam virando administradores dos sítios de fim de semana, me pareceu uma conclusão muito "paulista", não acontece em Santa Catarina, poderia acontecer em volta da cidade de São Paulo. Tanto que eu fiz até uma distinção em um texto meu. Para falar que há pluriatividade, a gente tem que dizer se é o agricultor, o homem ou a mulher, que está fazendo outras coisas, ou quando são os filhos, porque aqui, com a mineração e com a indústria têxtil, tinha muito agricultor que fazia as duas coisas. E também muitos filhos de agricultores que continuavam morando na propriedade. A hora que acabou isso é que a gente começa a falar de pluriatividade em Santa Catarina? [risos] E o novo rural foi um pouco assim.

É interessante. É um fenômeno interessante porque é um pessoal que de repente, através da agroecologia (as duas coisas surgiram meio juntas), começou a ir para o campo. Moradores da cidade, com propostas mais ecológicas, começaram a plantar e a criar de forma diferente. A isso, deu-se o nome de "novo rural". Eu organizei uma revista, 
aqui, e meu amigo Hugo Ratier, que é antropólogo, escreveu sobre isso na Argentina e chamou a atenção que, geralmente, os novos rurais eram ricos, comparados aos agricultores tradicionais [risos]. Um pouco isso, entende? Quem é que está indo, na Argentina, no caso? Ele chamou a atenção para uma coisa, "Quem são esses novos rurais?". Um que fez muita fama, que veio aqui, ajudou a destruir umas coisas, o francês, o Bové [José Bové]. Filho de professores universitários. Então, foi uma categoria que impressionou, porque nunca alguém tinha largado tudo para ser agricultor a não ser no tempo do anarquismo, das comunidades igualitárias. Não tinha isso. De repente, começou a acontecer um novo rural, assim, na França.

Entrevistadores: Certo, mas você considera o emprego dessa nova categoria "novo rural" adequada?

Maria Ignez Silveira Paulilo: Olha, eu nunca usei porque acho que é um pouco restrita a alguns lugares e tipos de produto. Claro que você fala nos novos rurais, mas nos meus estudos, assim, foi uma categoria que não me ajudou muito, eu não topo muito com eles, são raros. Agora, quem estuda deve entrevistar vários e ver como eles pensam. Agora eu, enquanto estudante do rural, ela não me ajuda muito porque eu estou estudando Santa Catarina e não estou estudando em volta de São Paulo ou de grandes centros. A Paola Capellin me contou que foi visitar uma mulher que criava cabritinhos, coisas mais lindinhas do mundo, e foi mostrar os filhotinhos pra ela com anéis de brilhante no dedo. Então, tem coisas interessantes. Mas, para mim, aqui em Santa Catarina, não é ainda uma categoria amplamente explicativa. Agora, para quem estuda essas pessoas que decidiram ir para o rural, sejam muitas ou poucas, espalhadas ou concentradas, a categoria novo rural deve fazer bem mais sentido. Existe um rural novo no Brasil, neste sentido? Acho que não. Novo rural pode ser uma categoria para pensar um grupo, que pode aumentar, pode não aumentar. Mas que exista um novo rural no Brasil, eu acho um pouco de exagero. Claro que mudou, mas tudo mudou, há novas cidades, novos bairros, novos carros, novos tudo. Não acho que essa categoria é suficiente para quebrar o entendimento que tínhamos de alguns fenômenos... 
Algumas categorias existentes foram simplesmente abandonadas. Como quando eu falo do feminismo, de repente, no Brasil, praticamente se abandonou a ideia de desigualdade econômica para se estudar mais reconhecimento e reprodução, mas a desigualdade está aí. Até eu brinquei uma vez, quando eu estava no Chile, e falei: "Primeiro foi sexo sem filho, agora é filho sem sexo e a miséria continua tão cristã quanto moura, "tan cristiana quanto mora", para brincar com uma frase de um poema satírico de Francisco de Quevedo [1580-1645]. Principalmente para os espanhóis, cristãos e mouros não deveriam ter nada em comum. Aí foi uma gargalhada geral porque, realmente, você começa a trocar muito de categorias e a miséria mesmo, a pobreza, tão cristã quanto moura, está aí. A questão fica meio de lado, mudam-se as ênfases, mas não fica resolvida.

Então eu acho que a categoria novo rural não pode obscurecer outras categorias. Claro que o rural se tecnificou, aconteceu muita coisa. A gente tem que rever as categorias o tempo todo, mas não sei se todas as revisões levam a maior compreensão. Novo rural é um conceito genérico demais. Talvez por eu ser uma pesquisadora de campo, gosto de conceitos mais operacionais.

\section{Entrevistadores: Categorias empíricas?.}

Maria Ignez Silveira Paulilo: Prefiro não chamar de categorias empíricas, porque, antigamente (e talvez mesmo hoje), se a gente falasse que utilizava "categorias empíricas", queria dizer que você criava o conceito a partir da pesquisa de campo. Você estava lá e a própria realidade falava com você. Eu acho que categoria empírica às vezes dá certo, às vezes não dá. É mais fácil não dar certo. Você pode criar algumas categorias empíricas quando você conhece muito bem a região que estuda. Um pensador de campo que conhece bem o que ele está fazendo, daí ele pode criar, mas, mesmo assim... Está apoiado em muito conhecimento teórico prévio. Por exemplo, Bourdieu. Bourdieu ajudou muito a Sociologia brasileira, a Antropologia também, porque ele é de campo! Por isso que os conceitos de Bourdieu a gente operacionaliza mais fácil, a gente dá um jeito. Já Giddens [Anthony Giddens], não é, Giddens não é de campo. Mas Giddens tem uma coisa interessante. Ele dá muito valor aos pensadores de campo que o ajudaram a pensar. 
Inclusive as feministas. Então você vê o livro "Sociologia", do Giddens, tem um capítulo sobre feminismo. Quando eu li, por exemplo, a "Dominação Masculina”, do Bourdieu, fiquei com tanta raiva! Ele não falou nada - nisso eu já tinha 40 anos de feminismo - que as feministas já não sabiam! Aí, a Miriam Grossi consertou meu pensamento. Bourdieu ter escrito sobre o feminismo na academia francesa legitimou essa área de estudos. Ele legitimou os estudos feministas, vê que interessante! Ele estudou rural, ele estudou tudo isso, mas ele teve que escrever "Dominação Masculina" para dizer que um grande pensador também pensava em feminismo.

Eu, às vezes, falo mais de feminismo do que de rural. Agora, esse grupo de Newcastle [Reino Unido] estudava o rural da Inglaterra com uma tranquilidade tremenda. Eles eram de campo, estudos de caso. Eu gostava do jeito deles. Inclusive o Terry Marsden, o Graziano traduziu. Ele co-orientou a tese do Mior [Luiz Carlos Mior]. O grupo se desfez... Eu adoro o conceito de localidade deles! O local como uma arena e não uma comunidade. As ações coletivas que lá acontecem são resultantes de jogo de forças, não de consensos. Mas eles também têm muito a ideia do conceito de trabalhar em rede. A ideia de trabalhar com a perspectiva de redes nunca me seduziu. Eu gosto de ler o trabalho dos outros, mas de fazer, não. Então essa parte de rede que eles desenvolveram não me emocionou muito. Mas, as outras partes, por exemplo, a de que o rural é uma construção, sim. Porque as pessoas pensam que a gente, que é do rural, quando chega lá, enxerga tudo. Eles que são especialistas em rural escrevem todo um texto maravilhoso sobre a construção do rural, como o rural é construído em várias épocas. Quer dizer, a gente sabe disso, embora muitos vissem (ainda veem? Acho que não) o professor de Metodologia e, também, quem pesquisava o rural, como aquele que considerava que o mundo era dado, ninguém entendia ou imaginava que a gente lia epistemologia, que a gente conhecia epistemologia. Agora, esse pessoal de Newcastle, eles eram seis, eram muito bons para juntar teoria e campo. Os que estão ainda pesquisando não o deixaram de ser. Terry Marsden continua sendo. Philip Lowie veio aqui, a Júlia [Júlia Guivant] o trouxe, não me lembro o ano. Mas não atraiu muita gente. Eu sei, eu fui na conferência, mas ele falou de outras coisas, eu queria que ele falasse desse pedaço que eu adoro, das diferentes construções do rural, porque a gente não engole um autor com casca e tudo; 
você gosta mais de um pedaço da obra que de outro. A gente, na verdade, dialoga com eles.

Entrevistadores: Um dos textos mais conhecidos e citados da produção sobre mundo rural é um texto seu chamado "O peso do trabalho leve". Foi publicado em 1987 na revista Ciência Hoje. Você poderia contar para a gente sobre a produção deste artigo?

Maria Ignez Silveira Paulilo: Foi em 87 que foi publicado. Eu defendi minha tese em 87. Não sei quem me pediu o texto. A decisão de escrever para a revista Ciência Hoje foi do meu orientador de mestrado, Albertino Rodrigues. Eu escrevi e ele foi parecerista. E ele assinou o parecer, apesar de que parecerista não precisa assinar. Falou um monte de coisa. "Você não pôs nada aqui! Você deve incluir esta experiência aqui...". Ele foi meu professor de graduação, desde o primeiro ano, e foi meu orientador de mestrado. Eu li o parecer ouvindo a voz dele, como se estivesse falando. Aí, eu refiz nem sei quantas vezes. Ele dizia “não serve”. Aí eu disse: “Desisto, desisto porque não dá, não fica bom, não entra, não vai”. Aí, ele escreveu assim: “Um pouco mais de paciência!”. Mas eu o ouvia falando comigo! “Um pouco mais de paciência!”. Assim, bem autoritário. Aí parece que veio a luz. Mas eu falei: “Eu tinha desistido, o texto não saía”. Aí, quando ele escreveu "Um pouco mais de paciência", eu mandei o artigo de novo: "Só falta fechar o texto", me responderam. Mas os jornalistas fizeram um trabalho tão lindo! O texto estava mais pesado, sem mudar minhas palavras, eles fizeram um trabalho com aquele texto fazendoo ficar mais leve.

Agora, "O peso do trabalho leve", todo mundo pergunta de onde eu tirei este título. Eu falo, não sei, acho que foi quando eu li “A insustentável leveza do ser”, do Milan Kundera. Eu via outros títulos como “mulheres não sei o quê", mas ninguém gostava, aí eu coloquei: "O peso do trabalho leve”. Ah!, se eu tivesse jogado na loteria! Aquele Cláudio, cartunista, fez um cartum engraçadíssimo do texto, usando as palavras das mulheres. Ele fez até um fulano sentado na cama: "fulana, faz isto; fulana, faz aquilo; agora, enrola aquele cigarrinho que só você sabe fazer”. Olha, o texto fez muito sucesso. Tem gente que xerocou (aquela era a época do xerox) e pregou na parede. Aquela charge 
do Claudio foi o maior sucesso. A Delma [Delma Pessanha] tinha me falado: "Quando você publicar na revista Ciência Hoje, você vai ver como repercute, as pessoas leem". Mas eu não esperava tanto. Esse texto já completou 30, em 2017, 30 anos. Um dia recebi uma carta do Ministério do Trabalho, quando eu me aposentei. Eu sou tão ansiosa para estas coisas que eu pensei: "Negaram a minha aposentadoria...", embora eu tenha trabalhado mais anos do que precisava. Aí, eu abri e dizia algo assim: se eu, como autora, permitia que eles pusessem esse texto no portal deles. Eu, como autora, detentora do direito moral... Se a revista publicou é ela que tem o direito. Do jeito que eles puseram! Esse texto, a Igreja já tinha publicado, e aconteceu em muitos outros lugares, sem autorização nenhuma! Já fizeram de tudo com esse texto e, mais de 20 anos depois, esse pedido! Saí rindo sozinha. Porque eu fiquei muito tensa. Quando abri o envelope, eu estava sozinha, descendo a escada e andando pelo campus, eu fui rindo sozinha o caminho todo, aí encontrei alguém e falei: “você não acredita o que está escrito aqui! Já fizeram de tudo com o texto e agora vêm pedir licença!”. Mas que eu esperasse essa repercussão, não! Depois, quando fui para a Inglaterra fazer pós-doutorado, eu completei o texto com mais uma pesquisa sobre produtoras de leite, que no texto da Ciência Hoje não tem. Completei, mandei traduzir, e enviei para algumas pessoas. Me serviu de passaporte. Me ajudou. Mas o pessoal brinca muito. O peso do trabalho leve. Acho que foi o título, a charge.

Também não é assim que o texto saiu levinho. Eu, naquelas alturas, 87 (eu comecei a fazer campo sobre agricultura em 1975), em 1987 já eram 12 anos, 12 anos que eu fazia campo. Quando eu escrevi, eu tinha feito campo em São Paulo, campo no Nordeste, tinha passado pelo Norte, tinha feito campo em Santa Catarina, tinha 12 anos de trabalho de campo! Não é que saiu do nada, né? E para escrever deu muito trabalho, se não fosse o Albertino Rodrigues! Só quando entendi assim, o peso do trabalho leve, é sobre isso que eu vou falar, desse trabalho de mulher que ocorre e nem se vê, parece que clareou. Mas demorou. E outra, os pareceres do Albertino ajudaram. Então, é esta a história d'O peso do trabalho leve. Eu não esperava essa repercussão tremenda. Mesmo pesquisando outros temas, estava vendo as mulheres porque eu era (e sou) feminista. As feministas falam da cegueira com relação às mulheres. E é verdade, não se enxerga. Quando eu fiz 
esta coletânea [Mulheres Rurais - Quatro décadas de diálogo, Editora da UFSC, 2016] me disseram: “Se nesta coletânea não sair ‘O peso do trabalho leve’, não dá!”.

Entrevistadores: A questão da sucessão na propriedade é um grande embate na agricultura familiar por conta da dificuldade da reprodução das famílias em virtude da emigração, das famílias pequenas e tudo o mais. Você vê isso como um problema, tem acompanhado o debate?

Maria Ignez Silveira Paulilo: Eu vou falar de uma perspectiva muito feminista para discutir a sucessão. Mas, uma coisa que me invoca é as mulheres não levarem terra mesmo! Tanto que o pessoal duvida muito de mim. Eu lembro uma vez que a Ilse [Ilse Scherer-Warren], filha de agricultores, e o Ari [Ari Minella], que vem de família de agricultores, falaram "na minha casa todo mundo recebeu herança". Isso acontece, todo mundo recebe quando a terra já não é mais importante, todos os filhos estudaram, têm outras profissões. Quer dizer, aquela ideia de que mulher não herda terra, nem meus colegas, vindos de agricultura familiar, acreditam. Tanto que uma falou: "Imagine, no caso do meu avô, do meu pai, todos herdaram!”. Eu perguntei: “Herdaram em proporções iguais?”. Isso ela não soube responder. Porque tem muitos pais que eram um pouco mais abertos, davam dinheiro, alguma coisa para a mulher, mas o comum era a máquina de costura para ela trabalhar, uma vaca... Os pais davam enxoval, alguns mais outros menos. E a que não casava, ficava solteira, nem ia estudar, não ganhava nada. Mas, nunca ninguém se interessou pelas solteiras no mundo rural. O Bourdieu estudou o solteiro [risos]. Aí cada vez que eu perguntava sobre as solteiras, diziam: "Elas ficam jogadas de um lado para o outro". E eu vi. As que não casam, cuidam dos pais. Depois, morrem os pais, vocês pensam que elas ficam com a casa? Ela vai morar com o irmão ou irmã e ajuda em tudo!

Podem falar o que quiserem, a mulher não herda! Mas se você falar isso aqui no meu departamento [na UFSC], os exemplos são sempre os das famílias para quem a terra não é mais importante ou, se não, é tão pequena que os pais já venderam e foram para a cidade. A mulher só pode fazer agricultura se ela casar. Na Inglaterra eu li sobre uma experiência de mulheres lésbicas que resolveram ser agricultoras e fizeram um espaço 
para elas. Uma coisa diferentíssima. Mas, no Brasil não tem, são diferentes. Agora, quando eu pergunto, por exemplo, sobre o sucessor, aí eu quero saber de mulher, é um assunto que ninguém toca. Você quer um tabu na vida? Todos os movimentos de mulheres têm coragem para tudo, menos para tocar nesse assunto. Elas só reivindicam terra quando é do governo, da reforma agrária, então reivindica. Mas, na família, não. A última vez que eu perguntei, uma líder do MMC [Movimento de Mulheres Camponesas] falou: “Este não é mais o problema, Ignez, nem sucessor tem! Não vamos discutir isto". Mas elas nunca quiseram discutir isso. Então, que as mulheres têm mais estudo no rural, todo mundo sabe. Os pais sabem que elas não vão ter lugar lá e mandam estudar. Então eu fico com esta pergunta: talvez não tenha sucessor mesmo, seja homem ou mulher? Mas alguém perguntou: "Se abrisse a sucessão para as mulheres, alguma coisa mudava ou não?". Eu não sei. Eu realmente não sei porque eu nunca vi.

Entre os caboclos, as brasileiras falam que elas herdam também, mas é tudo muito regional. Depois, você lê a Margarida Moura, que estuda caboclos, e a ideia é que como ela nunca ganha nada, quando ela ganha um pouquinho, já está bem. Eu conheci caboclas que tinham seu pedacinho de terra, o pai deu, mas não é a regra. Por exemplo, às vezes o pai só tem filhas, o filho não quer. Regra rígida mesmo não tem, quem vai suceder? Agora não sei se abrisse para as filhas, se resolvia também. Porque na França, a Miriam Grossi fala que as mulheres não querem ficar no meio rural. $O$ trabalho sobre o celibato do Bourdieu eu adoro. Eu li o Bourdieu quando não existia tradução, ele não coloca vírgula nem ponto, você vai ficando sem fôlego. Hoje eu leio melhor inglês do que francês. Mas tinha que ler. Eu li muito em francês quando fiz doutorado, no início dos anos 1980. Ele mostrou que se dizia que os homens não casavam e ele via que as estatísticas, que as taxas de casamento, não mudavam, não diminuíam. Pesquisando, ele percebeu que quem não casava era o dono da terra, por isso chamava atenção, que era justo o herdeiro. Mas daí é aquela história, o trabalho na roça é muito duro. A Miriam Grossi fala que as mulheres preferem trabalhar no correio da cidadezinha, fazendo qualquer coisa, mas não ficar no campo. Mas e agora, com essa valorização das mulheres agricultoras que está acontecendo, com essa nova preocupação ecológica, será que nada muda? As mulheres do MMC falam que querem ficar no campo. Porém, as moças, o que estão fazendo? Elas 
estão estudando para ser técnicas em agroecologia. Eu não estou vendo um movimento delas para debater a questão da herança.

A holandesa Ineke van Halsema foi morar junto com produtores do Rio Grande do Sul, por volta de 1990, e fez uma monografia muito bem feita. Cito como exemplo para meus alunos. Ela usou diversas técnicas. Pena que não foi traduzida. Ela usou muitas técnicas: observação participante, entrevistas, enquetes curtas... Todas as técnicas que pôde. Ela chamou a atenção para uma coisa que eu nunca tinha percebido: ela fala que o dote não tem nada a ver com herança. Que o dote, tradicionalmente, é algo que a mulher recebe antes de casar para poder ser independente. No Brasil, as mulheres ganhavam máquina de costura, enxoval, uma vaca ou porca, é uma coisa diferente... Aí que ela chamou minha atenção, eu não tinha feito doutorado ainda, eu era bem nova, mas eu percebi a importância do que ela dizia. Eu conheci a Ineke pessoalmente, inclusive. O que ela afirmou foi o seguinte: "O trabalho da mulher não é considerado trabalho. O homem herda a terra porque trabalhou e a mulher não herda porque se considera que não trabalhou”. Na verdade, não é herança que você ganha sem fazer nada? Então, por que o moço que sai para estudar não ganha terra?

A gente usa o termo herança e dote de maneira errada. Não com o significado que tiveram originalmente. E eu, depois de muito tempo de campo, eu desconfiava. Quando eu estava com as mulheres passeando na roça, as mais velhas, elas tinham uma revolta: “Trabalhei tanto quanto meus irmãos e não herdei nada”. Essa afirmação começou a ficar recorrente e eu comecei a sair sozinha com as mulheres por ali para ver se eu escutava de novo. Uma estava com uma dor no estômago horrorosa naquele dia, aí a mulher falou: “Hoje mesmo fui no cartório assinar! Ah, é por isso que estou com esta dor no estômago!”. Não sei se ela assinou a desistência ou a venda da sua parte da terra a preços simbólicos, já que no Brasil, pelo Código Civil, todos os filhos herdam. Estava com dor de raiva! Aí eu percebi que elas assinam, mas não sabem o que assinam. Eu tive alunas de pós-graduação, que vieram da agricultura familiar, e parece que a memória delas vira fumaça! Pergunto: “O que foi que você assinou - doação ou vendeu mais barato?”, não sabem, não lembram... Muitas delas diziam que faziam uma venda fictícia, por um preço baixo. Muito tempo depois, eu descobri outra coisa que eu não podia imaginar. O pai de 
família vende ficticiamente a terra para o vizinho, que revende ficticiamente para o filho herdeiro. Todo mundo sabe. Depois que eu soube (não iria adivinhar nunca porque é segredo muito bem guardado), perguntei: “Mas, e se o vizinho ficar com a terra?”. Resposta: "Isso não existe porque a comunidade inteira controla". Pelo Código Civil brasileiro, todos os filhos herdam igual. Eu acho engraçado porque isso nunca foi respeitado. Nunca. Então, a lei no Brasil, neste sentido, eles burlam de tudo quanto é jeito. Só se você não fizer papel nenhum ou morarem todos os herdeiros juntos, na mesma propriedade. Mas, no fim, algum papel (documento) se faz. Não é como em lugares remotos que ninguém tem escritura nenhuma. Tem. Então, para isso, eles burlam. Agora, essa de venda fictícia? Aí eu perguntei: “como eles faziam com os impostos?”. Não sei. Isso é burlar mesmo. Então, você vê, o que se faz para excluir alguns herdeiros, que são os homens que vão para a cidade estudar e as mulheres. Olha que no Código Civil brasileiro faz tempo que todos os filhos herdam.

Eu conheci um agricultor que, como ele tinha ido estudar, agricultor forte, como eles falam, excelente agricultor, já velho, ele tinha uma mágoa tremenda porque, como ele foi estudar, o pai não deu terra a ele. Ele comprou a terra. Engraçado que isso magoa, embora seja feito de comum acordo. O que eu achei interessante foi essa mágoa das mulheres. Porque a Ineke disse: "As mulheres parecem se conformar muito bem com isso". É a única coisa que eu discordo dela. Mesmo que ela tenha feito no Rio Grande do Sul, em outro estado, é a mesma tradição. As mulheres têm uma mágoa profunda que nunca ninguém viu. Uma vez, o Klaas Woortmann, sobre um estudo feito no Nordeste, disse: "O que eu faço com a dor de uma mulher?”. O que a gente faz com a dor, vamos dizer, da Maria? Porque é o seguinte: a família só podia fazer o casamento de uma das filhas, então a filha mais velha namorava e fizeram aquele casamentão, com direito a festa e enxoval. A segunda, não queriam que namorasse, implicavam com o namorado, mas um dia saiu todo mundo e a deixaram sozinha, facilitaram o rapto, como se diz, o moço veio e roubou a moça. Quer dizer, a primeira ganhou tudo aquilo e a segunda, por que a deixaram levar? Era uma estratégia porque você não podia fazer a mesma coisa para todas as filhas. E essa moça percebeu e tem uma grande mágoa. Então eu falo: o que eu faço com essa dor e mágoa dessas mulheres? Todo mundo está discutindo a sucessão 
e você viu alguém falar de mulher no problema da sucessão? Alguém falou que as mulheres não herdam? Mas alguém viu a dor das mulheres? Alguém perguntou para elas se queriam herdar terra?

A agricultura familiar tem suas estratégias de sobrevivência, toda vida ela teve. Quando falaram do que viveriam os filhos dos sem-terra assentados, eu falei: "Gente, as legiões romanas eram feitas de sem-terra. Eles ganhavam terras na Palestina, na África, nas áreas conquistadas. Desde que o mundo é mundo, a agricultura familiar deu um jeito, nem que fossem legiões romanas". Lembra daquele que fala, acho que é Eric Wolff, que os camponeses deram ótimos soldados para os países da Europa? É verdade. Então, por exemplo, toda a vida, a agricultura familiar teve problemas, ela tinha que ter muitos braços para trabalhar e não tinha terra para todo mundo; a diminuição da natalidade já foi uma coisa que se alterou não faz um século. Um holandês me falou que em seu país não tinha problema de sucessão, porque o casal tinha dois filhos, um filho. Um ficava com a terra e outro ficava trabalhando na terra, que vale uma fortuna. Já foi uma grande novidade a diminuição do número de filhos. Outra novidade que estou vendo são as estratégias atuais de sobrevivência. Pela lei, o filho do agricultor parece-se com o príncipe Charles, que nunca reina porque a rainha, me disseram, jurou que reina até a morte. 0 filho herdeiro fica na terra, mas é o pai que é o dono da propriedade, quando ele vai adquirir a maioridade? É uma situação difícil. Há muitos anos, eu conversei com uma italiana e ela me disse que, na Itália, estavam tentando fazer uma legislação para a agricultura familiar, que contemplasse problemas como este, tornando os filhos maiores sócios no empreendimento, por exemplo. Não sei no que deu. A França tem seu Direito Agrário. Em nosso país, tudo se rege pelo Código Civil, complementado por legislações particulares, como o PRONAF. Nossa constituição tem artigos que reforçam a função social da terra e outros que defendem mais a propriedade privada. É por isso que dizemos que temos juízes mais agraristas e outros mais civilistas; as decisões dependem da interpretação do juiz e das normas constitucionais que escolhe para embasar suas decisões.

Aquele assentamento bem coletivizado no Oeste, em Dionísio Cerqueira [Assentamento Conquista da Fronteira], quando a pessoa fica maior de idade, ela se 
torna sócia. Mas é engraçado porque o homem trabalha para o coletivo o dia inteiro e a mulher, meio período. Um dos líderes reconhece a desigualdade, mas disse que o cuidado da casa e dos filhos ainda fica com a mulher. Então, o que o agricultor está fazendo para não ficar sem sucessor? Ele arrenda um pedaço de terra para o filho para que ele tenha mais autonomia e renda própria. Ou deixa um ou mais ramos das atividades, como a avicultura, a suinocultura, a produção de leite, aos cuidados de filhos adultos. A persistência da agricultura familiar ao longo da história sempre foi atribuída a essa sua elasticidade, essa capacidade de adaptação. São muitos os que já previram seu fim. Percebendo que vai ficar sem herdeiro, o agricultor vai criando estratégias, ele dá mais autonomia, ele faz mil coisas, mas a legislação não muda. Não há empenho em incluir a agricultura familiar como um agente importante da economia do país. Os agricultores vão sobrevivendo como podem.

Não se discute o papel da agricultura familiar no novo momento em que estamos vivendo, e isso não só no Brasil. A revolução verde já está se esgotando em termos de mais produtividade, além de que, ela não resolveu o problema da fome e acentuou as agressões ao meio ambiente. Obriga-se o agricultor a burlar as muitas e, às vezes, contraditórias, legislações que não foram feitas pensando nele (nem o consultaram), depois o acusam de ignorante, individualista, pouco empreendedor, de tudo que possa desqualificá-lo. Com o agronegócio destruindo o meio ambiente, como essa poluição das águas que estamos vendo, peixes morrendo entupidos de plástico, como não pensar na agricultura familiar como um elemento de importância fundamental para resistir a este capitalismo agrário predatório? E as mulheres, como ficam? Neste caso, não temos nem dois tipos de juiz. Se a mulher abandonar a terra porque o marido é violento, acabou, fica sem. Ela tinha direito! Antigamente a mulher tornava-se sócia da terra no Brasil, através da comunhão total de bens quando se casava. Com a Lei do divórcio, acho que de 1977, as coisas mudaram. A herança recebida pelo marido, mesmo depois de casado, é só dele, isso deixa a mulher ao Deus dará. Elas não sabem. Uma, quando contei, disse: "Fique quieta, não vou contar para o meu marido". A Carmem Deere chamou a atenção para isso. Enquanto nos outros países da América Latina tentaram colocar a mulher como sócia quando ela não era, o Brasil foi na linha contrária. Agora, por que não ter uma 
legislação própria para o rural? A legislação civil é assim depois do divórcio: você casa com comunhão parcial de bens. Esse é o regime oficial; se você não abre a boca, você chega lá e casa com comunhão parcial de bens. Se você quiser comunhão total de bens, tem que fazer um outro contrato, mas alguém esclarece? Eu perguntei para minhas alunas: “Quando você foi casar no civil, o cartório explicou?" Não! Existem três regimes de casamento no Brasil: regime de comunhão parcial, comunhão universal e separação total. Ninguém avisa. Então quando você casa, você casa pela legislação oficial. Porque alguns cartórios avisam, mas outros não. Não sei quantos avisam. Um pouco que eu pedi para uma bolsista investigar, as explicações são muito raras.

Entrevistadores: Tem algum tema que você gostaria de comentar e que não perguntamos?

Maria Ignez Silveira Paulilo: O que eu gostaria de registrar é que eu queria muito que a parte de Humanas da Universidade Federal de Santa Catarina se dedicasse mais ao estudo da agricultura e do rural. Agora, como fazer, está difícil. Valmir Stropassolas, do Centro de Ciências Agrárias, fez questão de trazer o encontro das Redes Rurais para cá, foi um esforço grande dele e de outros alunos ligados ao NAF [Núcleo de Estudos sobre Agricultura Familiar, da UFSC]. Saiu um bom congresso, mas não atraiu o pessoal de humanas da UFSC. Eu gostaria muito que houvesse um investimento. Eu noto que há muitos alunos da graduação que vão à minha sala, querem estudar o rural, mas não encontram disciplinas optativas para fazer! Os alunos fizeram até um abaixo assinado pedindo mais investimento na área de estudos rurais, mas só deu confusão. Houve mais preocupação com a legalidade do abaixo assinado, que foi algo espontâneo, do que com o tema em questão. Está certo que não há mais professores que se dediquem a essa área entre os efetivos. Por que tem que ser professor efetivo? O regimento tem suas limitações, mas toda a vida os colegiados (do curso, do departamento, da pós-graduação) foram feitos para isto, decidir em situações consideradas excepcionais e nos famosos “casos omissos". A última frase dos regimentos é sempre algo assim: "Em casos excepcionais ou omissos, o colegiado decide". Se os regimentos se bastassem, se fosse só para se seguir a lei à risca, não precisaria existir colegiado para nada, mesmo com o risco de criarmos mordaças para nós mesmos, pedras legislativas para tropeçarmos. Mas 
percebi que não houve simpatia nenhuma por parte dos professores do meu departamento. A reação me foi inesperada. Muitos são contratações novas e eu os conheço pouco. Para mim foi um pouco traumático. Para os alunos interessados também. Talvez tivesse que ter tido mais diálogo. Mas, realmente, dada a forma como o departamento reagiu, perdi as esperanças. Por sorte, tem o Valmir Stropassolas e o Ademir Cazella, na Agronomia, e os alunos vão fazer disciplinas com eles. Acho que devemos ampliar também a relação com a UDESC; tem coisas interessantes acontecendo por lá.

Na UFSC, meus colegas afirmaram que os concursos estão sendo feitos para áreas mais genéricas, como Teoria Sociológica, Ciência Política, Metodologia de Pesquisa, ao invés de Sociologia Rural, Sociologia Urbana... Não sou contra isso, só que o profissional genérico não existe. Todos que prestam concurso têm sua área específica de estudo, não importa, o que é importante é que os aprovados dominem as disciplinas de formação básica, que tenham tido uma sólida formação profissional antes de terem optado por uma especialidade. Mas o que parece é que se considera especialistas em outras áreas como sociólogos ou cientistas políticos (a Antropologia tem seu departamento próprio) propriamente ditos, mas os especialistas em estudos rurais, não. O especialista em rural é um cientista social como qualquer outro. Ele fez todas as cadeiras obrigatórias que todo mundo fez! Ele tem toda a formação clássica necessária. Você sabe que na Inglaterra vi a mesma coisa? Os estudiosos do rural se queixarem de discriminação? Pensei, será que aqui também? Um pouco assim, se você é do rural, você só sabe aquilo. Eu estava num encontro do Chile, acho que em 1994, onde se esperava a presença de umas 200 pessoas e vieram mais que o dobro. Um dos organizadores falou: "Nós mesmos não sabemos quantos somos". Você faz um congresso de rural e sempre vem muita gente, sinal que essa área atrai estudiosos de diferentes áreas e níveis, gerando muitas inquietações. Porém, em um estado tão rural como é Santa Catarina, nunca houve muitos pesquisadores sobre o tema na academia. Tanto que se você olhar meu currículo, quando eu ainda tinha energia, eu participava de três a cinco congressos por ano para me atualizar. Não era assim tudo na internet, não. Eu tinha que ir lá. Não dá para se igualar agricultores com outros trabalhadores. 
O pessoal acha que a tecnologia venceu tudo, que a terra se corrige de qualquer jeito, que se faz chover, que se pode controlar a produção como em uma fábrica, mas não é assim. Conforme professores e alunos vão se distanciando de suas origens rurais, mais se esquecem de certas especificidades. Já tive colega que se admirou de que a vaca, para dar leite, precisa ser fecundada, ter o bezerro e, depois, ser ordenhada. O animal não cresce e começa a dar leite. Já a galinha virgem é que bota ovo, informação que surpreendeu uma outra colega. Mais um argumento usado para diminuir a importância do rural é a informação, muito difundida e defendida, de que só estão na agricultura pouco mais de $20 \%$ da população. Só tem essa proporção porque o censo considera como cidade, como urbano, espaços que em outros países são considerados rurais. O José Eli da Veiga até escreveu um livro sobre isso: “Cidades Imaginárias”.

Eu acho interessante é que se considera que um grupo de surfistas na praia, ou jovens que frequentam determinado shopping, podem dar um trabalho de pósgraduação. Por que, na agricultura, eles dizem que tem pouca gente? Quantos milhões? E em termos de importância, não são os agricultores que produzem grande parte de nossa alimentação? Gosta-se muito de falar que a diferença entre campo e cidade está diminuindo. Que os agricultores estão se "urbanizando". O que é se urbanizar? Vestir-se, se comportar e falar como os jovens da cidade? Isso é mais importante que o fato de que eles continuam sendo produtores e produtoras de alimentos? No urbano, você tem música country, por que não se fala que a cidade está se ruralizando? Eu fico louca com a expressão "tratar com urbanidade”! É porque só o urbano é gentil? Cortesia, vem de corte. Só os cortesãos sabiam ser corteses, o resto era raça bruta. Parece que continua um pouco essa ideia! Tudo tem que ser pior no meio rural. Quando se fala de violência doméstica, todo mundo acha que o pior é no rural! Claro que existe o fato de que uma mulher vivendo em uma casa isolada pode ficar mais vulnerável, pode ser mais difícil pedir socorro. Nas favelas acontece da família da mulher morar ao lado e não conseguir evitar a violência. Matam-se mulheres em prédios de apartamento, dentro de elevadores, até dentro do próprio carro da polícia! O que eu queria era que aqui em Santa Catarina a Universidade Federal, entidade a qual pertenço, na área de humanas, tivesse mais 
interesse pelos estudos rurais, só que eu não sei se isso vai acontecer. É sintomático que eu esteja sendo entrevistada, neste momento, pelo pessoal da UDESC.

Entrevistadores: Maria lgnez Paulilo, nós agradecemos por esta conversa tão interessante.

Recebida em: 03/07/2019

Aprovada em: 03/11/2019

Universidade do Estado de Santa Catarina - UDESC Centro de Ciências Humanas e da Educação - FAED

Revista PerCursos

Volume 20 - Número 43 - Ano 2019 revistapercursos@gmail.com 